\title{
International Union of Basic and Clinical Pharmacology. C. Nomenclature and Properties of Calcium-Activated and Sodium-Activated Potassium Channels
}

\author{
Leonard K. Kaczmarek, Richard W. Aldrich, K. George Chandy, Stephan Grissmer, Aguan D. Wei, and Heike Wulff \\ Departments of Pharmacology and Cellular and Molecular Physiology, Yale School of Medicine, New Haven, Connecticut (L.K.K.); Center for \\ Learning and Memory and Department of Neuroscience, University of Texas at Austin, Austin, Texas (R.W.A.); Laboratory of Molecular \\ Physiology in the Infection and Immunity Theme, Lee Kong Chian School of Medicine, Nanyang Technological University, \\ Singapore (K.G.C.); Institute of Applied Physiology, Ulm University, Ulm, Germany (S.G.); Center for Integrative Brain Research, \\ Seattle Children's Research Institute, Seattle, Washington (A.D.W.); and Department of Pharmacology, School of Medicine, \\ University of California, Davis, California (H.W.)
}

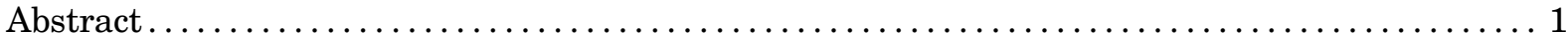

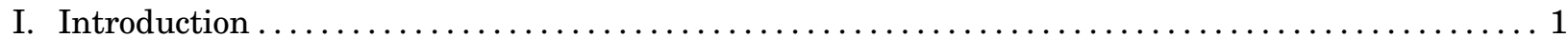

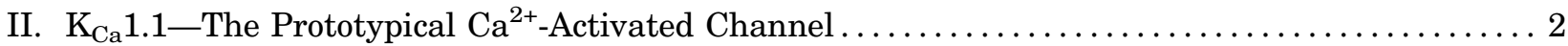

III. The $\mathrm{K}_{\mathrm{Ca}} 2$ Family_Small Conductance Channels Regulated by Calmodulin .............. 4

IV. $\mathrm{K}_{\mathrm{Ca}} 3.1-\mathrm{A}$ Multifunctional Intermediate-conductance Channel Regulated by Calmodulin ...... 5

V. The $\mathrm{K}_{\mathrm{Na}} 1$ Family-Channels Regulated by Intracellular $\mathrm{Na}^{+}$and $\mathrm{Cl}^{-} \ldots \ldots \ldots \ldots \ldots \ldots \ldots$

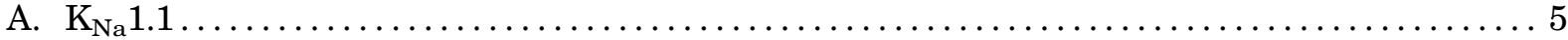

B. $\mathrm{K}_{\mathrm{Na}} 1.2-\mathrm{A}$ Widely Distributed Channel Sensitive to $\mathrm{Na}^{+}$and $\mathrm{Cl}^{-} \ldots \ldots \ldots \ldots \ldots \ldots \ldots . \ldots$

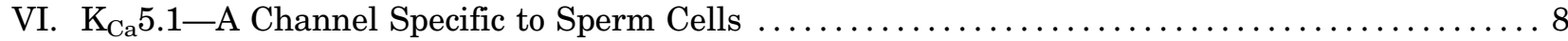

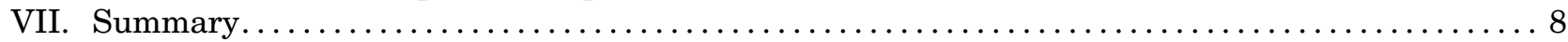

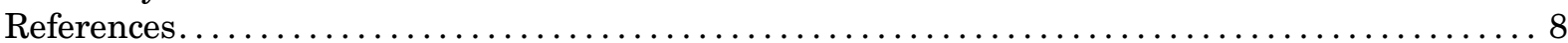

Abstract _ A subset of potassium channels is regulated primarily by changes in the cytoplasmic concentration of ions, including calcium, sodium, chloride, and protons. The eight members of this subfamily were originally all designated as calcium-activated channels. More recent studies have clarified the gating mechanisms for these channels and have documented that not all members are sensitive to calcium. This article describes the molecular relationships between these channels and provides an introduction to their functional properties. It also introduces a new nomenclature that differentiates between calcium- and sodium-activated potassium channels.

\section{Introduction}

The first evidence that elevations of intracellular $\mathrm{Ca}^{2+}$ can increase the $\mathrm{K}^{+}$permeability of the plasma membrane was obtained by demonstrating that chelation of $\mathrm{Ca}^{2+}$ suppresses the flux of $\mathrm{K}^{+}$out of red blood cells (Gardos, 1958). Intracellular injection of $\mathrm{Ca}^{2+}$ into neurons of both invertebrates and vertebrates was subsequently found to activate a $\mathrm{K}^{+}$conductance (Krnjević and Lisiewicz, 1972;
Meech, 1972). The discovery of a Drosophila mutant termed slowpoke (slo) (Elkins et al., 1986), in which a $\mathrm{Ca}^{2+}$-dependent component of $\mathrm{K}^{+}$current is lacking in indirect flight muscles, eventually led to the identification of the first gene that encodes a $\mathrm{Ca}^{2+}$-activated $\mathrm{K}^{+}$channel (Atkinson et al., 1991; Adelman et al., 1992) and its mammalian homolog (Butler et al., 1993). The properties of this channel in heterologous expression systems

The authors serve as the Subcommittee on Calcium-Activated and Sodium-Activated Potassium Channels of the Nomenclature Committee of the International Union of Pharmacology (NC-IUPHAR).

Address correspondence to: Leonard K. Kaczmarek, Departments of Pharmacology and Cellular and Molecular Physiology, Yale School of Medicine, New Haven, CT 06520. E-mail: leonard.kaczmarek@yale.edu

dx.doi.org/10.1124/pr.116.012864.

ABBREVIATIONS: AHP, afterhyperpolarization; IUPHAR, International Union of Basic and Clinical Pharmacology; RCK, regulator of conductance for $\mathrm{K}^{+}$ions; Slack, sequence like a calcium-activated $\mathrm{K}$ channel; Slick, sequence like an intermediate conductance $\mathrm{K}$ channel. 
corresponded very closely to a channel that had by then been very well characterized in many types of tissues as well as in lipid bilayers. This $\mathrm{K}^{+}$channel is sensitive to both $\mathrm{Ca}^{2+}$ and transmembrane voltage and had been termed the BK or MaxiK channel because of its large unitary conductance (Contreras et al., 2013). This prototypical $\mathrm{Ca}^{2+}$-gated channel is termed $\mathrm{K}_{\mathrm{Ca}} 1.1$ in the standardized nomenclature that is used to classify $\mathrm{K}^{+}$ channels (Wei et al., 2005). Like all the other channels discussed in this review, a functional $\mathrm{K}^{+}$channel is comprised of a tetramer of these pore-forming proteins.

Genes that encode other $\mathrm{Ca}^{2+}$-dependent $\mathrm{K}^{+}$channels were subsequently discovered by screening cDNA libraries for sequences resembling the ion-selective pore of known $\mathrm{K}^{+}$channels, and then testing the expressed channels for sensitivity to changes in internal $\mathrm{Ca}^{2+}$ levels. After $\mathrm{K}_{\mathrm{Ca}} 1.1$, the next two classes of channels to be discovered were found to be gated by $\mathrm{Ca}^{2+}$ but, unlike $\mathrm{K}_{\mathrm{Ca}} 1.1$, to be insensitive to membrane voltage. These are the $\mathrm{K}_{\mathrm{Ca}} 2$ family, which consists of three members $\left(\mathrm{K}_{\mathrm{Ca}} 2.1, \mathrm{~K}_{\mathrm{Ca}} 2.2\right.$, and $\mathrm{K}_{\mathrm{Ca}} 2.3$ ) (Köhler et al., 1996) and the $\mathrm{K}_{\mathrm{Ca}} 3$ family, which contains only a single member $\left(\mathrm{K}_{\mathrm{Ca}} 3.1\right)$ (Ishii et al., 1997b; Joiner et al., 1997). These two families have also been termed SK and IK channels, based on the fact that, when compared with $\mathrm{K}_{\mathrm{Ca}} 1.1$ channels, their unitary conductance is either small $\left(\mathrm{K}_{\mathrm{Ca}} 2\right.$ channels) or intermediate $\left(\mathrm{K}_{\mathrm{Ca}} 3.1\right)$ (Adelman et al., 2012). In fact, we now know that $\mathrm{K}_{\mathrm{Ca}} 2$ channels are responsible for the current observed after injections of $\mathrm{Ca}^{2+}$ into neurons and that $\mathrm{K}_{\mathrm{Ca}} 3.1$ is the channel first detected in red blood cells.

Three other genes were assigned to the family of $\mathrm{Ca}^{2+}$-dependent $\mathrm{K}^{+}$channels, based on predictions that their structures resemble those of $\mathrm{K}_{\mathrm{Ca}} 1.1$. Although these were given the names $\mathrm{K}_{\mathrm{Ca}} 4.1, \mathrm{~K}_{\mathrm{Ca}} 4.2$, and $\mathrm{K}_{\mathrm{Ca}} 5.1$, they have more commonly been referred to in the literature by other names including those used in the original publications; Slack or Slo2.2 (Joiner et al., 1998; Yuan et al., 2003), Slick or Slo2.1 (Bhattacharjee et al., 2003; Yuan et al., 2003), and SLO3 (Schreiber et al., 1998), respectively. Figure 1 shows the phylogenetic relations among these channels, as well as between the smaller conductance channels. The Slack and Slick

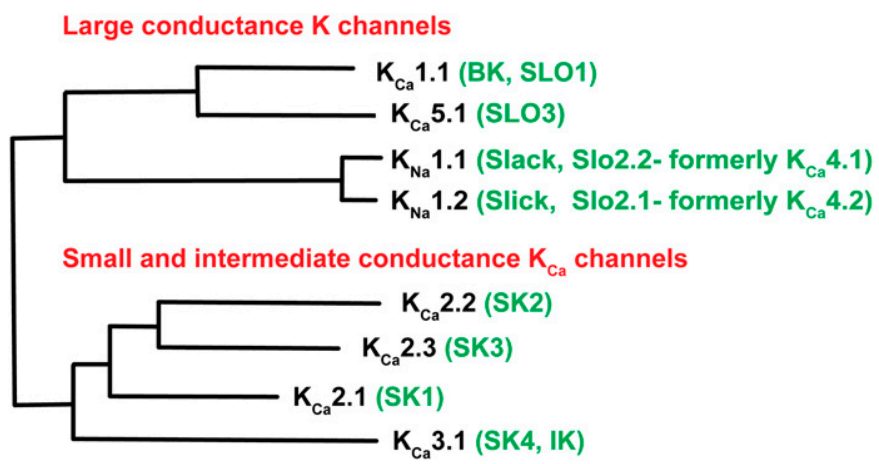

Fig. 1. Phylogenetic relations among members of the $\mathrm{Ca}^{2+}-$ and $\mathrm{Na}^{+}-$ dependent $\mathrm{K}^{+}$channel families. channels form a subgroup that is distinct from $\mathrm{K}_{\mathrm{Ca}} 1.1$ and $\mathrm{K}_{\mathrm{Ca}} 5.1$. In the past 15 years, it has become evident that these channels are not activated by intracellular $\mathrm{Ca}^{2+}$ but that they are regulated by changes in cytoplasmic levels of $\mathrm{Na}^{+}$as well as $\mathrm{Cl}^{-}$(Bhattacharjee et al., 2003; Yuan et al., 2003; Kaczmarek, 2013). This review will cover the general properties of each of the members of the $\mathrm{Ca}^{2+}$ - and $\mathrm{Na}^{+}$- dependent $\mathrm{K}^{+}$channels, with a particular focus on the channels that have been found to be activated by $\mathrm{Na}^{+}$. We also propose a new nomenclature $\left(\mathrm{K}_{\mathrm{Na}} 1.1, \mathrm{~K}_{\mathrm{Na}} 1.2\right)$ for the two channels that are activated by $\mathrm{Na}^{+}$(see Fig. 1). This nomenclature is more consistent with the fact that $\mathrm{Na}^{+}$-activated $\mathrm{K}^{+}$currents in native cells have generally been termed $\mathrm{K}_{\mathrm{Na}}$ currents (Kameyama et al., 1984; Dryer, 1994; Bhattacharjee and Kaczmarek, 2005). The new nomenclature has been implemented in the International Union of Basic and Clinical Pharmacology (IUPHAR) database (http://www.guidetopharmacology.org/GRAC/ FamilyDisplayForward?familyId=69) and in the related Concise Guide to Pharmacology for voltage-gated ion channels (Alexander et al., 2015).

\section{II. $\mathrm{K}_{\mathrm{Ca}}$ 1.1-The Prototypical $\mathrm{Ca}^{2+}$-Activated Channel}

The $\mathrm{K}_{\mathrm{Ca}} 1.1$ channel, also known as the BK, Maxi K, or Slo1 channel, has probably received more experimental attention than all of the other channels in this family combined, and its properties have been reviewed recently (Contreras et al., 2013). One factor that has contributed to the popularity of this channel is its very large unitary conductance, $200 \mathrm{pS}$ or more in symmetrical $\mathrm{K}^{+}$concentrations (Marty, 1981). Because it is expressed in a wide range of tissues, it is the easiest channel to detect when patch clamping cells and it is readily reconstituted into lipid bilayers (Pallotta et al., 1981; Latorre et al., 1982). $\mathrm{K}_{\mathrm{Ca}} 1.1$ channels become activated by elevations of $\mathrm{Ca}^{2+}$ in the range of tens to hundreds micromolar. These relatively high physiologic concentrations are achieved close to plasma membrane $\mathrm{Ca}^{2+}$ channels or at sites of $\mathrm{Ca}^{2+}$ release from intracellular stores.

As described above, the gene for $\mathrm{K}_{\mathrm{Ca}} 1.1$ was first identified by genetic studies in Drosophila (Atkinson et al., 1991; Adelman et al., 1992; Butler et al., 1993). Structural studies of the channel protein have been carried out both by X-ray crystallography and cryoelectron microscopy (Wang and Sigworth, 2009; Yuan et al., 2012; Wrighton et al., 2015). One feature that distinguishes $\mathrm{K}_{\mathrm{Ca}} 1.1$ (and also $\mathrm{K}_{\mathrm{Ca}} 5.1$, see below) from all other $\mathrm{K}^{+}$channels is that it has seven transmembrane domains (Fig. 2). In addition to the canonical six transmembrane domains S1-S6 that are common to all of the voltage-dependent $\mathrm{K}_{\mathrm{V}}$ family channels, there is an additional domain termed S0, preceding S1 (Meera et al., 1997). As a result, the $\mathrm{N}$-termini of the $\mathrm{K}_{\mathrm{Ca}} 1.1$ 


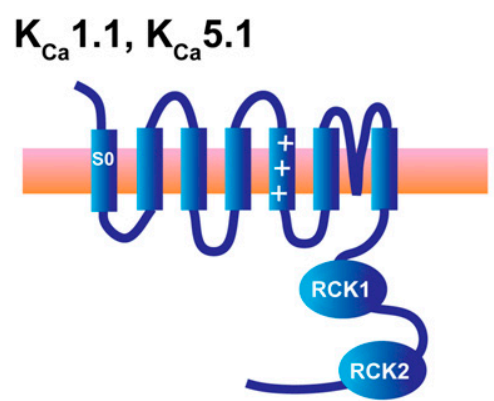

$\mathrm{K}_{\mathrm{ca}} 2.1, \mathrm{~K}_{\mathrm{ca}} 2.2, \mathrm{~K}_{\mathrm{ca}} 2.3, \mathrm{~K}_{\mathrm{ca}} 3.1$
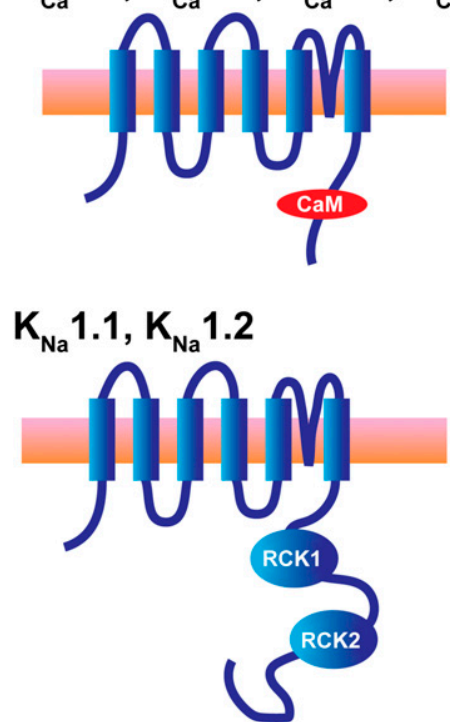

Fig. 2. Schematic representations of the transmembrane topology of $\mathrm{K}_{\mathrm{Ca}}$ and $\mathrm{K}_{\mathrm{Na}}$ channels.

and $\mathrm{K}_{\mathrm{Ca}} 5.1$ proteins are located on the outside rather than the inside of a cell.

The open probability of $\mathrm{K}_{\mathrm{Ca}} 1.1$ channels is sensitive to membrane voltage, and this sensitivity is conferred by charged residues in the $\mathrm{S} 2, \mathrm{~S} 3$, and $\mathrm{S} 4$ domains (Stefani et al., 1997; Horrigan and Aldrich, 1999, 2002; Ma et al., 2006). These move in response to changes in transmembrane voltage even in the absence of internal $\mathrm{Ca}^{2+}$. Activation by elevations of $\mathrm{Ca}^{2+}$ occurs by shifting the voltage dependence of the channel to progressively more negative potentials. Binding sites for $\mathrm{Ca}^{2+}$ ions are located in two regions of the extended cytoplasmic C-terminal termed the RCK1 and RCK2 domains (for regulator of conductance for $\mathrm{K}^{+}$ions) (Jiang et al., 2002; Wu et al., 2010; Yuan et al., 2010). A region termed the $\mathrm{Ca}^{2+}$ bowl located in RCK2 contains multiple negatively charged residues (Schreiber and Salkoff, 1997; Bao et al., 2004). The eight RCK domains in each tetrameric $\mathrm{K}_{\mathrm{Ca}} 1.1$ channel together form a "gating ring" that opens on binding of $\mathrm{Ca}^{2+}$. This conformational change is coupled to the transmembrane regions through a cytoplasmic linker region next to the activation gate in the $\mathbf{S} 6$ segment. This allosteric mechanism leads to an increase in open probability following $\mathrm{Ca}^{2+}$ binding
(Horrigan and Aldrich, 1999; Jiang et al., 2002; Wu et al., 2010; Miranda et al., 2013).

The $\mathrm{Ca}^{2+}$-sensitivity of $\mathrm{K}_{\mathrm{Ca}} 1.1$ channels, as well as their kinetic behavior, sensitivity to pharmacological agents, and response to activation of protein kinases, varies considerably in different tissues (Contreras et al., 2013). Although there is only one gene that encodes these channels, such diversity is achieved by alternative splicing of mRNAs (Navaratnam et al., 1997; Rosenblatt et al., 1997) and by the fact that the properties of the channel are substantially modified by auxiliary $\beta$-subunits. Alternative splicing not only determines the response to $\mathrm{Ca}^{2+}$ but also the targeting of the channel to the plasma membrane or to intracellular organelles such as mitochondria (Lagrutta et al., 1994; Xie and McCobb, 1998; Chen et al., 2005; Fodor and Aldrich, 2009; Singh et al., 2012). Binding of the $\mathrm{K}_{\mathrm{Ca}} 1.1$ $\alpha$ subunit to one of four different auxiliary subunits $(\beta 1$, $\beta 2, \beta 3$, and $\beta 4$ ) alters voltage dependence, activation rate, sensitivity to a wide range of drugs, and determines whether the channel inactivates during sustained depolarization (Brenner et al., 2000; Uebele et al., 2000; Xia et al., 2000; Contreras et al., 2012). The properties of the channels can be further modified by association with $\gamma$-subunits, also known as leucinerich repeat proteins (Yan and Aldrich, 2012), and by binding to heme, which may allow the channel to respond to changes in redox state of the cell (Tang et al., 2003).

Although $\mathrm{K}_{\mathrm{Ca}} 1.1$ channels are expressed in many different tissues, their activity is particularly prominent in smooth muscle cells, including those of the vascular endothelium (Contreras et al., 2013). Channel activation, in response to synthesis of nitric oxide (NO) and activation of cGMP-dependent protein kinase, produces muscle relaxation, altering blood vessel diameter and blood pressure. Other tissues in which $\mathrm{K}_{\mathrm{Ca}} 1.1$ channels have been studied include sensory hair cells of the cochlea of lower vertebrates, where they establish the tonotopic gradient that determines the frequency of sound to which each cell responds (Roberts et al., 1990; Bai et al., 2011). In neurons, as well as in pancreatic $\beta$-cells, $\mathrm{K}_{\mathrm{Ca}} 1.1$ channels regulate action potential firing and secretion (Rajan et al., 1990; Faber and Sah, 2003).

As described above, the pharmacological properties of $\mathrm{K}_{\mathrm{Ca}} 1.1$ channels depend on their association with auxiliary subunits. The scorpion toxins charybdotoxin, iberiotoxin, and slotoxin are effective pore blockers for these channels (Kaczorowski et al., 1996; Garcia-Valdes et al., 2001). Paxilline is also an effective blocker, widely used in studies in the nervous system (Sanchez and McManus, 1996). A variety of compounds that activate $\mathrm{K}_{\mathrm{Ca}} 1.1$ channels, such as NS1619, are also commonly used experimental agents ( $\mathrm{Li}$ et al., 2003). In addition, KCa1.1 channels are very sensitive to relatively low concentrations of ethanol, which potentiate their 
activity (Treistman and Martin, 2009). Both the potentiating effects of ethanol and development of subsequent tolerance to its actions depend on both direct interactions with the KCa1.1 $\alpha$-subunit, the presence of the $\beta 4$ subunit, and the lipid environment (Mulholland et al., 2009).

Mutations in either the $\alpha$ - or $\beta$-subunits of $\mathrm{K}_{\mathrm{Ca}} 1.1$ channels, as well as changes in expression levels of these proteins, are linked to a variety of clinical conditions including hypertension, diabetes, asthma, and epilepsy (Fernández-Fernández et al., 2004; Du et al., 2005; Seibold et al., 2008; Wang et al., 2012). For example, a mutation of the $\alpha$-subunit D434G in the cytoplasmic linker that couples the gating ring to the activation gate increases channel open probability, resulting in epilepsy (Yang et al., 2010).

\section{The $\mathbf{K}_{\mathbf{C a}} 2$ Family-Small Conductance Channels Regulated by Calmodulin}

This family consists of three members, $\mathrm{K}_{\mathrm{Ca}} 2.1$, $\mathrm{K}_{\mathrm{Ca}} 2.2$, and $\mathrm{K}_{\mathrm{Ca}} 2.3$ (commonly also termed SK1, SK2, and SK3), each of which has a unitary conductance of $\sim 10 \mathrm{pS}$ when measured in symmetrical $\mathrm{K}^{+}$solutions (Köhler et al., 1996). Their properties and physiologic functions have been reviewed (Stocker, 2004; Adelman et al., 2012). In their transmembrane organization, $\mathrm{K}_{\mathrm{Ca}} 2$ channels resemble the voltage-dependent $\mathrm{K}_{\mathrm{V}}$ family of channels with six alpha-helical transmembrane segments, S1-S6, and a consensus $\mathrm{K}^{+}$-selective pore sequence between S5 and S6 (Fig. 2). Unlike the voltage-dependent channels, however, there is only a small number of positively charged residues in the fourth transmembrane segment S4. Consistent with the role of the $\mathrm{S} 4$ segment as a voltage sensor in $\mathrm{K}_{\mathrm{V}}$ channels, the $\mathrm{K}_{\mathrm{Ca}} 2$ family channels have linear currentvoltage relations and are insensitive to changes in transmembrane voltage. With a $K_{\mathrm{D}}$ for activation by $\mathrm{Ca}^{2+}$ of only several hundred nanomolar, they are substantially more sensitive to small changes in cytoplasmic $\mathrm{Ca}^{2+}$ levels than are the $\mathrm{K}_{\mathrm{Ca}} 1.1$ channels (Köhler et al., 1996). This sensitivity can be attributed to the fact that the $\alpha$-subunits of these channels form a heteromeric complex with calmodulin and that it is the binding of $\mathrm{Ca}^{2+}$ to this constitutively associated calmodulin rather than to the $\alpha$-subunit of the channel itself that confers $\mathrm{Ca}^{2+}$ sensitivity (Xia et al., 1998).

In addition to calmodulin, $\mathrm{K}_{\mathrm{Ca}} 2.2$ and $\mathrm{K}_{\mathrm{Ca}} 2.3$ channels in their native state enter into a multiprotein complex containing casein kinase 2 and protein phosphatase 2A (Bildl et al., 2004; Allen et al., 2007). Within this complex, casein kinase phosphorylates a threonine residue in calmodulin, reducing sensitivity of the channel to $\mathrm{Ca}^{2+}$ and increasing the rate at which channels close after transient elevation of cytoplasmic $\mathrm{Ca}^{2+}$ (Bildl et al., 2004). When activated within the complex, protein phosphatase 2A reverses this effect (Allen et al., 2007).
The physiologic role of $\mathrm{K}_{\mathrm{Ca}} 2$ family channels has been investigated most extensively in the nervous system, where they are expressed at high levels in cerebellar Purkinje cells and in pyramidal cells of the hippocampus and cerebral cortex (Stocker and Pedarzani, 2000; Sailer et al., 2002). $\mathrm{K}_{\mathrm{Ca}} 2.3$ channels are also present in nonneuronal tissues, including the vascular endothelium, urinary bladder smooth muscle, and cardiac tissue (Taylor et al., 2003; Chen et al., 2004; Rosenbaum et al., 2012). In many types of neurons, a prominent action of $\mathrm{K}_{\mathrm{Ca}} 2$ channels is to generate a $\mathrm{Ca}^{2+}$-dependent afterhyperpolarization (AHP) of the membrane that follows a burst of action potentials. $\mathrm{K}_{\mathrm{Ca}} 2$ channels thus regulate neuronal firing frequency and spike frequency adaptation (Adelman et al., 2012). There exist multiple components of AHPs, each with a different time course after the burst. Genetic deletion of the $\mathrm{K}_{\mathrm{Ca}} 2.2$ subunit abolishes the medium AHP, which decays over several hundreds of millisecond after a train of action potentials, but does not affect other components of the AHP (Bond et al., 2004).

$\mathrm{K}_{\mathrm{Ca}} 2$ channels may be closely coupled selectively with L-type calcium channels to allow for activation by $\mathrm{Ca}^{2+}$ nanodomains formed by $\mathrm{Ca}^{2+}$ influx through the calcium channels (Marrion and Tavalin, 1998). Neurotransmitter receptors that also elevate cytoplasmic $\mathrm{Ca}^{2+}$ levels, either by $\mathrm{Ca}^{2+}$ influx through the receptor as in the case of NMDA receptors (Oliver et al., 2000; Faber et al., 2005; Ngo-Anh et al., 2005), or by triggering release of $\mathrm{Ca}^{2+}$ from intracellular stores (Power and Sah, 2008; Klement et al., 2010), can also produce neuronal hyperpolarization by activating $\mathrm{K}_{\mathrm{Ca}} 2$ channels. The trafficking of $\mathrm{K}_{\mathrm{Ca}} 2.2$ channel subunits into and out of the spines on the dendrites of hippocampal neurons determines the onset and amplitude of longterm potentiation, a prolonged increase in excitatory synaptic transmission that follows repetitive synaptic stimulation of hippocampal pyramidal cells (Lin et al., 2008; Allen et al., 2011). $\mathrm{K}_{\mathrm{Ca}} 2$ channels thus seem to play an important role in learning and memory (Hammond et al., 2006).

The key pharmacological agent that has been used to characterize the properties of this family of small conductance $\mathrm{Ca}^{2+}$-activated $\mathrm{K}^{+}$channels, both in native neurons and expression systems, is the neurotoxin apamin, a component of bee venom that appears to be fully selective for this class of channel (Adelman et al., 2012). Although effectively a pore blocker, the selectivity for $\mathrm{K}_{\mathrm{Ca}} 2$ channels is determined by residues outside of the pore region itself (Ishii et al., 1997a; Nolting et al., 2007; Lamy et al., 2010). A variety of compounds that positively modulate these channels by apparently increasing their $\mathrm{Ca}^{2+}$ sensitivity have also been found (Christophersen and Wulff, 2015). The first of these to be characterized was 1-ethyl-2-benzimidazolinone (Devor et al., 1996), a compound that binds at the calmodulin-channel interface (Zhang et al., 2012a). Another activator, NS309, has been shown by X-ray 
crystallography to bind to a short region of the channel that links the cytoplasmic domain of $\mathrm{K}_{\mathrm{Ca}} 2.2$ to the $\mathrm{S} 6$ segment (Zhang et al., 2013a). This is believed to stabilize the open state of the channel and facilitate gating in the presence of the channel activator.

Based on the physiologic role of $\mathrm{K}_{\mathrm{Ca}} 2$ channels in regulating neuronal excitability, $\mathrm{K}_{\mathrm{Ca}} 2$ activators, which can reduce neuronal firing, are being investigated for the treatment of conditions characterized by hyperexcitability, such epilepsy, ataxia, and alcohol dependence (Lam et al., 2013). $\mathrm{K}_{\mathrm{Ca}} 2$ channel inhibitors in contrast have been suggested to improve learning and memory (Lam et al., 2013) and are being investigated preclinically for the treatment of atrial fibrillation based on the role of $\mathrm{K}_{\mathrm{Ca}} 2$ channels in modulating action potential duration in the heart (Grunnet et al., 2012).

\section{IV. $\mathbf{K}_{\mathbf{C a}} 3.1-A$ Multifunctional Intermediate- conductance Channel Regulated by Calmodulin}

$\mathrm{K}_{\mathrm{Ca}} 3.1$ channels are closely related to the $\mathrm{K}_{\mathrm{Ca}} 2$ family and were originally termed SK4 channels (Ishii et al., 1997b; Joiner et al., 1997). Their unitary conductance is, however, greater than that of $\mathrm{K}_{\mathrm{Ca}} 2$ channels, giving rise to the name IK (for intermediate conductance for $\mathrm{K}^{+}$), which has also been used widely to denote these channels. Like the $\mathrm{K}_{\mathrm{Ca}} 2$ family channels, the sensitivity of $\mathrm{K}_{\mathrm{Ca}} 3.1$ to $\mathrm{Ca}^{2+}$ is determined by its association with calmodulin (Fanger et al., 1999; Joiner et al., 2001) (Fig. 2).

The properties of $\mathrm{K}_{\mathrm{Ca}} 3.1$ closely match those of the first described $\mathrm{Ca}^{2+}$-activated $\mathrm{K}^{+}$conductance, the "Gardos channel" in red blood cells, where it is expressed at high levels and plays a role in volume regulation (Vandorpe et al., 1998; Hoffman et al., 2003). It is also the major $\mathrm{Ca}^{2+}$-activated $\mathrm{K}^{+}$channel in human $\mathrm{T}$ lymphocytes (Logsdon et al., 1997) and in other immune cells such as B lymphocytes, mast cells, macrophages, and microglia (Cahalan and Chandy, 2009; Feske et al., 2015). $\mathrm{K}_{\mathrm{Ca}} 3.1$ further plays a significant role in many other nonexcitable tissues such as the vascular endothelium, fibroblasts, dedifferentiated vascular smooth muscle cells, and secretory epithelia (Wulff and Köhler, 2013). In all these tissues, $\mathrm{K}_{\mathrm{Ca}} 3.1$ regulates $\mathrm{Ca}^{2+}$ signaling and membrane potential. Although two recent studies indicated that $\mathrm{K}_{\mathrm{Ca}} 3.1$ may be expressed in neurons and that it may contribute to the slow afterhyperpolarization that follows a burst of action potentials in neurons of the hippocampus (King et al., 2015; Turner et al., 2015), another study presented data that $\mathrm{K}_{\mathrm{Ca}} 3.1$ does not contribute to this slow AHP (Wang et al., 2016). The potential role of the channel in neurons therefore currently remains unclear.

Many of the pharmacological agents that activate the $\mathrm{K}_{\mathrm{Ca}} 2$ channels are also positive modulators of $\mathrm{K}_{\mathrm{Ca}} 3.1$ (Wulff and Christophersen, 2015) and are being investigated as novel endothelial-targeted antihypertensives because of the role of $\mathrm{K}_{\mathrm{Ca}} 3.1$ and $\mathrm{K}_{\mathrm{Ca}} 2.3$ in the endothelium-derived hyperpolarization vasodilator response (Brähler et al., 2009). The pharmacology of agents that suppress $\mathrm{K}_{\mathrm{Ca}} 3.1$ current, however, differs from that of the $\mathrm{K}_{\mathrm{Ca}} 2$ family. For example, $\mathrm{K}_{\mathrm{Ca}} 3.1$ is insensitive to apamin, but can be blocked by charybdotoxin and the small molecule TRAM-34 (Wulff et al., 2000). Genetic deletion and/or pharmacological treatment with TRAM34 have been used to demonstrate that $\mathrm{K}_{\mathrm{Ca}} 3.1$ potentially constitutes a novel target for immunosuppression in autoimmune diseases and stroke as well as for fibroproliferative disorders, asthma, and atherosclerosis (Wulff and Castle, 2010). However, the only clinical application of $\mathrm{K}_{\mathrm{Ca}} 3.1$ blockers has so far been for the treatment of sickle cell anemia, where senicapoc failed in Phase-3 clinical trials despite engaging its target as demonstrated by the observed improvements in hematocrit and erythrocyte hydration in the treated patients (Ataga et al., 2011).

\section{The $\mathrm{K}_{\mathrm{Na}} \mathbf{1}$ Family-Channels Regulated by Intracellular $\mathrm{Na}^{+}$and $\mathrm{Cl}^{-}$}

\section{A. $K_{N a} 1.1$}

The channel for which we now propose the name $\mathrm{K}_{\mathrm{Na}} 1.1$ in the official IUPHAR nomenclature was found to be inhibited rather than activated by cytoplasmic $\mathrm{Ca}^{2+}$ in the original study that expressed this channel in oocytes and mammalian cells (Joiner et al., 1998; Budelli et al., 2016). It was named Slack for "Sequence Like A Calcium-Activated K channel" because its unitary conductance $(\sim 65 \mathrm{pS}$ in physiologic solutions, $\sim 180 \mathrm{pS}$ in symmetric $\mathrm{K}^{+}$solutions) is intermediate between that of $\mathrm{K}_{\mathrm{Ca}} 1.1$ channels and that of most other $\mathrm{K}^{+}$channels. It has also been termed Slo2.2 and, in the earlier IUPHAR nomenclature, $\mathrm{K}_{\mathrm{Ca}} 4.1$, based on the premise that it was likely to resemble $\mathrm{K}_{\mathrm{Ca}} 1.1$ in its properties. It is, however, only $7 \%$ identical to $\mathrm{K}_{\mathrm{Ca}} 1.1$, and subsequent work established that it is gated primarily by changes in $\mathrm{Na}^{+}$and $\mathrm{Cl}^{-}$ concentrations (Bhattacharjee et al., 2003; Yuan et al., 2003; Yan et al., 2012). Its properties and physiologic functions have been reviewed recently (Kaczmarek, 2013).

$\mathrm{K}_{\mathrm{Na}} 1.1$ also differs from $\mathrm{K}_{\mathrm{Ca}} 1.1$ in that it lacks an $\mathrm{S} 0$ transmembrane domain and therefore resembles $\mathrm{K}_{\mathrm{V}}$ family and $\mathrm{K}_{\mathrm{Ca}} 2$ family channels in its transmembrane topology (Fig. 2). Although $\mathrm{K}_{\mathrm{Na}} 1.1$ currents are voltage dependent, the protein lacks the motif of repeated basic amino acids in the $\mathrm{S} 4$ segment that is characteristic of voltage-dependent channels and $\mathrm{K}_{\mathrm{Ca}} 1.1$. The complete structure of $\mathrm{K}_{\mathrm{Na}} 1.1$ in its closed state has been determined by cryoelectron microscopy (Hite et al., 2015) and that of the cytoplasmic C-terminal domain, under conditions that are likely to correspond to the open state, by X-ray crystallography (Yuan et al., 2010). As in $\mathrm{K}_{\mathrm{Ca}} 1.1$, there are two RCK domains in the extended $\mathrm{C}$ terminus of each $\mathrm{K}_{\mathrm{Na}} 1.1$ subunit in a tetrameric 
channel, and these form a cytoplasmic gating ring that, when it is constricted, closes the ion conduction pore. A potential binding site for $\mathrm{Na}^{+}$ions, which resembles a site conferring $\mathrm{Na}^{+}$dependence on $\mathrm{K}_{\mathrm{ir}} 3$ family channels (Sui et al., 1996), has been located in RCK2 and mutations at this site substantially lower $\mathrm{Na}^{+}$sensitivity (Zhang et al., 2010). Confirmation of the site(s) at which $\mathrm{Na}^{+}$binds will, however, require determination of the complete structure in the presence of $\mathrm{Na}^{+}$.

Several isoforms of $\mathrm{K}_{\mathrm{Na}} 1.1$ that differ in their kinetics of activation are produced by alternative splicing of RNA encoding this channel (Brown et al., 2008). One of these, which has been termed Slack-B $\left(\mathrm{K}_{\mathrm{Na}} 1.1 \mathrm{~B}\right)$ and has the longest cytoplasmic $\mathrm{N}$-terminal domain of the known isoforms, can form heteromers with $\mathrm{K}_{\mathrm{Na}} 1.2$ (Slick), whose properties are elaborated in the next section (Chen et al., 2009). The original studies of $\mathrm{K}_{\mathrm{Na}} 1.1$ expressed in Xenopus oocytes found that coexpression of Slack-B with $\mathrm{K}_{\mathrm{Ca}} 1.1$ gave rise to channels that had properties distinct from either channel alone, suggesting that the two subunits may interact (Joiner et al., 1998). Studies of its regional distribution, however, indicate that this is unlikely to be a major role for $\mathrm{K}_{\mathrm{Na}} 1.1$ subunits. Unlike the ubiquitous $\mathrm{K}_{\mathrm{Ca}} 1.1, \mathrm{~K}_{\mathrm{Na}} 1.1$ is primarily expressed in central and peripheral neurons, with little expression in other tissues except for the testes and kidney (Joiner et al., 1998; Bhattacharjee et al., 2002; Paulais et al., 2006; Brown et al., 2008; Nuwer et al., 2010; Rizzi et al., 2016).

Phosphorylation by protein kinase $\mathrm{C}$ of a serine residue in the cytoplasmic linker region between the RCK domains and the S6 transmembrane domain of $\mathrm{K}_{\mathrm{Na}} 1.1$ increases current amplitude (Santi et al., 2006; Barcia et al., 2012). The activity of $\mathrm{K}_{\mathrm{Na}} 1.1$ channels can be also regulated by their interaction with other cellular proteins. These include the transmembrane protein TMEM16C (Huang et al., 2013) and the Fragile X Mental Retardation protein (Brown et al., 2010; Zhang et al., 2012b), both of which enhance $\mathrm{K}_{\mathrm{Na}} 1.1$ channel activity. Interactions with several other cellular components, including the postsynaptic density protein PSD-95, have also been reported but their functional effects are not yet known (Uchino et al., 2003; Rizzi et al., 2015). Specific residues in the RCK domains have been identified that allow $\mathrm{K}_{\mathrm{Na}} 1.1$ channels to be activated by the membrane lipid phosphatidylinositol 4.5-bisphosphate (de los Angeles Tejada et al., 2012a) and by nicotinamide adenine dinucleotide (Tamsett et al., 2009). The open probability of $\mathrm{K}_{\mathrm{Na}} 1.1$ channels has also been reported to be enhanced by $17 \beta$-estradiol (Zhang et al., 2005) and by increases in $\mathrm{pH}$ (Ruffin et al., 2008).

Suppression of $\mathrm{K}_{\mathrm{Na}} 1.1$ expression using RNAi techniques indicates that this subunit accounts for a substantial component of sustained $\mathrm{K}^{+}$current in several types of neurons, including cortical pyramidal cell, medium spiny neuron of the striatum and mitral cell of the olfactory bulb (Budelli et al., 2009; Lu et al., 2010). The channel is also expressed at high levels in nociceptive neurons within the dorsal root ganglion, and suppression of current using several approaches, including deletion of the gene for $\mathrm{K}_{\mathrm{Na}} 1.1$, enhances neuronal excitability and produces hypersensitivity of animals to several pain-inducing stimuli (Gao et al., 2008; Tamsett et al., 2009; Nuwer et al., 2010; Huang et al., 2013; Lu et al., 2015; Martinez-Espinosa et al., 2015). Deletion of the gene in mice also has a variety of more wide-ranging effects on behavior, including an inability to reverse a previously learned behavior (Bausch et al., 2015).

Human mutations in $\mathrm{K}_{\mathrm{Na}} 1.1$ result in a variety of early onset epilepsies associated with very severe intellectual disability (Kim and Kaczmarek, 2014). These include malignant migrating partial seizures in infancy (Barcia et al., 2012; Ishii et al., 2013; McTague et al., 2013; Rizzo et al., 2016), autosomal dominant frontal lobe epilepsy (Heron et al., 2012; Kim et al., 2014), Ohtahara syndrome (Martin et al., 2014), and other epilepsies (Juang et al., 2014; Vanderver et al., 2014). Mutations in the gene for $\mathrm{K}_{\mathrm{Na}} 1.1$ have also been documented in autism (Iossifov et al., 2014). When expressed in Xenopus oocytes, the disease-causing mutations in $\mathrm{K}_{\mathrm{Na}} 1.1$ generate currents that are 3 - to 22 -fold greater than those of wild-type channels, with no change in levels of channel protein or mRNA (Barcia et al., 2012; Martin et al., 2014; Milligan et al., 2014). For a subset of these mutations, changes in voltage dependence or $\mathrm{Na}^{+}$sensitivity contribute to the increase in current (Kim et al., 2014; Tang et al., 2016). Nevertheless, these factors may be insufficient to account quantitatively for the increase in macroscopic current. In single channel recordings, the probability of opening of a Slack channel is increased if it is present in a cluster with neighboring Slack channels, and such cooperativity is greatly enhanced in the disease-causing mutations (Kim et al., 2014), suggesting that interchannel interactions as well as intrinsic changes in gating account for the observed gain-in-function in the mutants.

No pharmacological agents that act on $\mathrm{K}_{\mathrm{Na}} 1.1$ selectively have yet been discovered. Quinidine is a very effective blocker of these channels in both expression systems and neurons (Bhattacharjee et al., 2003; Yang et al., 2006, 2007; Milligan et al., 2014; Rizzo et al., 2016). It has been reported that quinidine ameliorated the symptoms of a patient with malignant migrating partial seizures in infancy, but because this agent blocks a wide variety of other channels, the mechanism is not known (Bearden et al., 2014). Other nonspecific blockers that suppress $\mathrm{K}_{\mathrm{Na}} 1.1$ channels include bepredil, clofilium, and barium ions (Bhattacharjee et al., 2003; Yang et al., 2006; de Los Angeles Tejada et al., $2012 \mathrm{~b}$ ). These channels can also be activated by several pharmacological agents including bithionol, loxapine, 
and niclosamide (Yang et al., 2006; Biton et al., 2012). Although bithionol also activates $\mathrm{K}_{\mathrm{Ca}} 1.1$ ( $\mathrm{Li}$ et al., 2003), loxapine appears to be specific for $K_{\mathrm{Na}}$ channels over $\mathrm{K}_{\mathrm{Ca}} 1.1$ (Biton et al., 2012).

\section{B. $K_{N a} 1.2-A$ Widely Distributed Channel Sensitive to $\mathrm{Na}^{+}$and $\mathrm{Cl}^{-}$}

The channel for which we now propose the name $\mathrm{K}_{\mathrm{Na}} 1.2$ in the IUPHAR nomenclature is very closely related to $\mathrm{K}_{\mathrm{Na}} 1.1$, being $\sim 74 \%$ identical in protein sequence, with the greatest divergence from $\mathrm{K}_{\mathrm{Na}} 1.1$ at the distal $\mathrm{C}$ terminus (Bhattacharjee et al., 2003). Because of its similarity in sequence to $\mathrm{K}_{\mathrm{Na}} 1.1$ (Slack) it was named Slick for "Sequence Like an Intermediate Conductance K channel." It is also referred to as Slo2.1 and, in the earlier IUPHAR nomenclature, $\mathrm{K}_{\mathrm{Ca}} 4.2$. As with $\mathrm{K}_{\mathrm{Na}} 1.1$, however, it has been found to be gated predominantly by $\mathrm{Na}^{+}$and $\mathrm{Cl}^{-}$(Bhattacharjee et al., 2003; Kaczmarek, 2013).

Although there have been no structural studies of $\mathrm{K}_{\mathrm{Na}} 1.2$ as yet, insights have been provided by mutagenesis (Garg et al., 2013), and its mechanisms of gating are likely to resemble those of $\mathrm{K}_{\mathrm{Na}} 1.1$. The unitary conductance of $\mathrm{K}_{\mathrm{Na}} 1.2$ in symmetrical $\mathrm{K}^{+}$solutions is $\sim 140 \mathrm{pS}$, and it is slightly less sensitive to changes in $\mathrm{Na}^{+}$and more sensitive to alterations in $\mathrm{Cl}^{-}$than is $\mathrm{K}_{\mathrm{Na}} 1.1$ (Bhattacharjee et al., 2003). As in $\mathrm{K}_{\mathrm{Na}} 1.1$, there is a $\mathrm{Na}^{+}$coordination motif in RCK2 that determines sensitivity to $\mathrm{Na}^{+}$(Thomson et al., 2015), and channel activity is regulated by binding to phosphatidylinositol 4.5-bisphosphate (de los Angeles Tejada et al., 2012a). Unlike $\mathrm{K}_{\mathrm{Na}} 1.1$, however, there exists a consensus ATP binding site after the second RCK domain of $\mathrm{K}_{\mathrm{Na}} 1.2$. The function of this site in cells is, however, not yet clear. Experiments using excised patches demonstrate that application of $5 \mathrm{mM}$ ATP or a nonhydrolyzable ATP analog reduced currents by $\sim 80 \%$ and that mutation of this consensus site abolished the effect of ATP (Bhattacharjee et al., 2003). Moreover, ATP and a nonhydrolyzable analog were both found to suppress $\mathrm{Na}^{+}$- and $\mathrm{Cl}^{-}$-activated $\mathrm{K}^{+}$channels in excised patches from auditory brain stem neurons that express $\mathrm{K}_{\mathrm{Na}} 1.2$ (Yang et al., 2007). In contrast, experiments with a $\mathrm{K}_{\mathrm{Na}} 1.2$-GFP fusion construct expressed in HEK cells failed to find an effect of adding ATP to patch pipettes on current amplitude (Berg et al., 2007). ATP was also found not to affect the increase in $\mathrm{K}_{\mathrm{Na}} 1.2$ currents produced by niflumic acid, a pharmacological activator of these channels (Garg and Sanguinetti, 2014). Thus the conditions under which ATP regulates these channels have yet to be completely established.

Coimmunoprecipitation and single channel studies have established that $\mathrm{K}_{\mathrm{Na}} 1.2$ coassembles with $\mathrm{B}$ isoform of $\mathrm{K}_{\mathrm{Na}} 1.1$ ( $\mathrm{K}_{\mathrm{Na}} 1.1 \mathrm{~B}$, Slack-B) to form heteromeric channels with properties distinct from those of either subunit alone (Chen et al., 2009). The formation of such heteromers requires the specific N-terminal domain of
Slack-B and apparently does not occur with the shorter $\mathrm{N}$-terminal splice variant $\mathrm{K}_{\mathrm{Na}} 1.1 \mathrm{~A}$ (Slack-A). In contrast to $\mathrm{K}_{\mathrm{Na}} 1.1, \mathrm{~K}_{\mathrm{Na}} 1.2$ currents, as well as those of heteromeric $\mathrm{K}_{\mathrm{Na}} 1.2 / \mathrm{K}_{\mathrm{Na}} 1.2$ channels are suppressed by activation of protein kinase C (Santi et al., 2006; Chen et al., 2009).

$\mathrm{K}_{\mathrm{Na}} 1.2$ channels are widely distributed throughout the nervous system and are also expressed in a variety of nonneuronal cells including cardiac cells (Bhattacharjee et al., 2003,2005; Yuan et al., 2003; Rizzi et al., 2015). A recent report suggests an important role for $\mathrm{K}_{\mathrm{Na}} 1.2$ (KCNT2) in controlling the migratory capacity of medulloblastoma cell lines, acting synergistically with $\mathrm{K}_{\mathrm{V}} 10.2$ (EAG2) potassium channels (Huang et al., 2015). In the nervous system, coexpression with $\mathrm{K}_{\mathrm{Na}} 1.1$ can be detected in some but not all types of neurons (Santi et al., 2006; Berg et al., 2007). Based on pharmacological experiments, a proposal has been made that a $\mathrm{K}_{\mathrm{Na}}$ channel, most likely $\mathrm{K}_{\mathrm{Na}} 1.2$, regulates $\mathrm{K}^{+}$flux across the inner membrane of mouse heart mitochondria and that channel activation is cardioprotective (Wojtovich et al., 2011).

One major feature that distinguishes $\mathrm{K}_{\mathrm{Na}} 1.2$ from the closely-related $\mathrm{K}_{\mathrm{Na}} 1.1$ channel is its sensitivity to small changes in cell volume. When expressed in oocytes, $\mathrm{K}_{\mathrm{Na}} 1.2$ currents are strongly stimulated by cell swelling and inhibited by a decrease in cell volume (Tejada et al., 2014). There are as yet no reported human mutations in $K C N T 2$, the gene encoding $\mathrm{K}_{\mathrm{Na}} 1.2$ channels, that could shed light on potential physiologic roles of $\mathrm{K}_{\mathrm{Na}} 1.2$. Nevertheless, several observations suggest that it serves a protective function during ischemia or tissue injury, the function proposed by the very first publication describing $\mathrm{Na}^{+}$-activated $\mathrm{K}^{+}$currents (Kameyama et al., 1984). In neurons, the promoter for the gene is regulated by nuclear factor- $\kappa \mathrm{B}$, which is activated under conditions of hypoxia or injury (Tomasello et al., 2015). In the nematode Caenorhabditis elegans, deletion of the gene for SLO-2, the ortholog to mammalian $\mathrm{K}_{\mathrm{Na}}$ channels, alters the sensitivity of the animals to hypoxia, although reports differ in the direction of the change in sensitivity (Yuan et al., 2003; Zhang et al., 2013b). Moreover, extrapolation of these findings to mammals is problematic, because, unlike the mammalian $\mathrm{K}_{\mathrm{Na}}$ channels, nematode SLO-2 is activated by $\mathrm{Ca}^{+}$rather than $\mathrm{Na}^{+}$, an effect that can be attributed to specific glutamic acid residues in RCK1of the nematode channel (Yuan et al., 2000; Zhang et al., 2013b). The RCK2 domain of SLO-2 more closely resembles those of $\mathrm{K}_{\mathrm{Na}} 1.1$ and $\mathrm{K}_{\mathrm{Na}} 1.2$ channels in that the domain corresponding to the $\mathrm{Ca}^{2+}$ bowl of $\mathrm{K}_{\mathrm{Ca}} 1.1$ contains repeated positively charged residues rather than the negative charges in $\mathrm{K}_{\mathrm{Ca}} 1.1$.

In common with $\mathrm{K}_{\mathrm{Na}} 1.1$, there are no known pharmacological agents that selectively target $\mathrm{K}_{\mathrm{Na}} 1.2$ channels. They are inhibited by quinidine, clofilium, and isoflurane (Bhattacharjee et al., 2003; Berg et al., 2007; 
de Los Angeles Tejada et al., 2012b). They are strongly activated by niflumic acid and other fenamates, although with low potency (Dai et al., 2010; Garg and Sanguinetti, 2012). These agents uncouple the channels from modulation by either $\mathrm{Na}^{+}$or transmembrane voltage and greatly increase current even in the absence of internal $\mathrm{Na}^{+}$ions. The action of fenamates, which is nonspecific in that they also affect many other channels including $\mathrm{K}_{\mathrm{Ca}} 1.1$ (Gribkoff et al., 1996), is biphasic, suggesting they bind to two distinct sites within $\mathrm{K}_{\mathrm{Na}} 1.2$ (Garg and Sanguinetti, 2012).

\section{VI. $\mathrm{K}_{\mathrm{Ca}}$ 5.1-A Channel Specific to Sperm Cells}

The $\mathrm{K}_{\mathrm{Ca}} 5.1$ channel, which is encoded by the KCNU1 gene, is more commonly referred to as SLO3. It was discovered through its homology to $\mathrm{K}_{\mathrm{Ca}} 1.1$ (Schreiber et al., 1998), and, of all the channels reviewed here, $\mathrm{K}_{\mathrm{Ca}} 5.1$ is most closely related to $\mathrm{K}_{\mathrm{Ca}} 1.1$ in sequence and structure, as determined by X-ray crystallography (Leonetti et al., 2012). Like $\mathrm{K}_{\mathrm{Ca}} 1.1, \mathrm{~K}_{\mathrm{Ca}} 5.1$ has seven transmembrane segments with an S0 segment before $\mathrm{S} 1$ and an extracellular $\mathrm{N}$ terminus (Fig. 2). When expressed in oocytes, the mouse channel is voltage dependent and sensitive to $\mathrm{pH}$, being activated by alkalinization and suppressed by acidification (Schreiber et al., 1998; Zhang et al., 2006a,b).

$\mathrm{K}_{\mathrm{Ca}} 5.1$ is expressed selectively in sperm cells, and its properties are regulated by LRRC52, a testis-specific accessory subunit (Schreiber et al., 1998; Leonetti et al., 2012; Zeng et al., 2015). Evidence strongly suggests that it corresponds to the large-conductance potassium channel that can be recorded from mature sperm. This native channel is activated by both voltage and internal alkalinization and has been termed KSper (Navarro et al., 2007). As sperm encounter the alkaline environment near the ovum in the female reproductive tract, the activation of KSper is believed to produce the membrane hyperpolarization that is observed during the process of sperm capacitation. Normal capacitation is required for sperm to become fully competent for fertilization.

The identification of $\mathrm{K}_{\mathrm{Ca}} 5.1$ with the sperm KSper channel has been well established in mice (Santi et al., 2010; Zeng et al., 2011, 2013). For human sperm, however, one report suggested that the native KSper channels is actually $\mathrm{K}_{\mathrm{Ca}} 1.1$ (Mannowetz et al., 2013). This conclusion was based on recordings of native currents from human sperm, which showed that the human channels have a $\mathrm{Ca}^{2+}$ dependence and pharmacological properties similar to those of $\mathrm{K}_{\mathrm{Ca}} 1.1$. Nevertheless, a more recent study indicated that, as in mice, the human KSper-like current is in fact encoded by human $\mathrm{K}_{\mathrm{Ca}} 5.1$ (Brenker et al., 2014). The explanation for the apparent contradiction offered by this study is that human $\mathrm{K}_{\mathrm{Ca}} 5.1$ channels are functionally different from the mouse channels. In particular, despite their strong sequence similarity, human $\mathrm{K}_{\mathrm{Ca}} 5.1$ channels are significantly more sensitive to activation by internal $\mathrm{Ca}^{2+}$ and less $\mathrm{pH}$ sensitive than the mouse channels, which makes them functionally similar to typical $\mathrm{K}_{\mathrm{Ca}} 1.1$ channels.

No pharmacological agents that selectively act on $\mathrm{K}_{\mathrm{Ca}} 5.1$ channels have been found, but they can be blocked by quinidine (Tang et al., 2010; SánchezCarranza et al., 2015) as well as by $\mathrm{Ba}^{2+}$ ions and quinine (Wrighton et al., 2015). As the specific factors that regulate the gating of $\mathrm{K}_{\mathrm{Ca}} 5.1$ in different species become established, it may become appropriate to rename this channel.

\section{Summary}

Research in the past 15 years has clarified the structural and functional relationships among $\mathrm{K}^{+}$channels that are gated by changes in intracellular concentrations of $\mathrm{Ca}^{2+}, \mathrm{Na}^{+}$, and protons, as well as their biologic roles in different cell types. These are now considered to fall into three distinct groups. The first group contains the ubiquitous large-conductance $\mathrm{Ca}^{2+}$-activated $\mathrm{K}_{\mathrm{Ca}} 1.1$ (BK) channel as well as the sperm-specific $\mathrm{K}_{\mathrm{Ca}} 5.1$ channel, which have seven transmembrane segments in each subunit and an extracellular $\mathrm{N}$ terminus. Gating of these channels is controlled by the ion binding directly to two RCK domains located in their extended cytoplasmic $\mathrm{C}$ termini. The second group is comprised of two channels activated by internal $\mathrm{Na}^{+}$and $\mathrm{Cl}^{-}$ions, for which we propose the names $\mathrm{K}_{\mathrm{Na}} 1.1$ and $\mathrm{K}_{\mathrm{Na}} 1.2$. These resemble the first group in that they have cytoplasmic C-terminal RCK domains that control gating and have large unitary conductances, but they have only six transmembrane segments in each subunit and their $\mathrm{N}$ termini are located intracellularly. The third group of channels is comprised of the small conductance channels, $\mathrm{K}_{\mathrm{Ca}} 2.1, \mathrm{~K}_{\mathrm{Ca}} 2.2$, and $\mathrm{K}_{\mathrm{Ca}} 2.3$, and the intermediate conductance channel $\mathrm{K}_{\mathrm{Ca}}$ 3.1. In contrast to the other channels, these are voltage independent and activation by $\mathrm{Ca}^{2+}$ occurs through the binding of $\mathrm{Ca}^{2+}$ to calmodulin, an integral component of the channel complex, rather than through direct binding of $\mathrm{Ca}^{2+}$ to the $\alpha$-subunits.

\section{References}

Adelman JP, Maylie J, and Sah P (2012) Small-conductance Ca2+-activated K+ channels: form and function. Annu Rev Physiol 74:245-269.

Adelman JP, Shen KZ, Kavanaugh MP, Warren RA, Wu YN, Lagrutta A, Bond CT, and North RA (1992) Calcium-activated potassium channels expressed from cloned complementary DNAs. Neuron 9:209-216.

Alexander SP, Catterall WA, Kelly E, Marrion N, Peters JA, Benson HE, Faccenda E, Pawson AJ, Sharman JL, Southan C, et al.; CGTP Collaborators (2015) The Concise Guide to PHARMACOLOGY 2015/16: Voltage-gated ion channels. $B r J$ Pharmacol 172:5904-5941.

Allen D, Bond CT, Luján R, Ballesteros-Merino C, Lin MT, Wang K, Klett N, Watanabe M, Shigemoto R, Stackman RW Jr, et al. (2011) The SK2-long isoform directs synaptic localization and function of SK2-containing channels. Nat Neurosci 14:744-749.

Allen D, Fakler B, Maylie J, and Adelman JP (2007) Organization and regulation of small conductance $\mathrm{Ca}^{2+}$-activated $\mathrm{K}^{+}$channel multiprotein complexes. J Neurosci 27:2369-2376.

Ataga KI, Reid M, Ballas SK, Yasin Z, Bigelow C, James LS, Smith WR, Galacteros F, Kutlar A, Hull JH, et al.; ICA-17043-10 Study Investigators (2011) Improvements in haemolysis and indicators of erythrocyte survival do not correlate with 
acute vaso-occlusive crises in patients with sickle cell disease: a phase III randomized, placebo-controlled, double-blind study of the Gardos channel blocker senicapoc (ICA-17043). Br J Haematol 153:92-104.

Atkinson NS, Robertson GA, and Ganetzky B (1991) A component of calciumactivated potassium channels encoded by the Drosophila slo locus. Science 253:551-555

Bai JP, Surguchev A, and Navaratnam D (2011) $\beta 4$-subunit increases Slo responsiveness to physiological $\mathrm{Ca} 2+$ concentrations and together with $\beta 1$ reduces surface expression of Slo in hair cells. Am J Physiol Cell Physiol 300:C435-C446.

Bao L, Kaldany C, Holmstrand EC, and Cox DH (2004) Mapping the BKCa channel's "Ca ${ }^{2+}$ bowl": side-chains essential for $\mathrm{Ca}^{2+}$ sensing. J Gen Physiol 123:475-489.

Barcia G, Fleming MR, Deligniere A, Gazula VR, Brown MR, Langouet M, Chen H, Kronengold J, Abhyankar A, Cilio R, et al. (2012) De novo gain-of-function KCNT1 channel mutations cause malignant migrating partial seizures of infancy. Nat Genet 44:1255-1259.

Bausch AE, Dieter R, Nann Y, Hausmann M, Meyerdierks N, Kaczmarek LK, Ruth $\mathrm{P}$, and Lukowski R (2015) The sodium-activated potassium channel Slack is required for optimal cognitive flexibility in mice. Learn Mem 22:323-335.

Bearden D, Strong A, Ehnot J, DiGiovine M, Dlugos D, and Goldberg EM (2014) Targeted treatment of migrating partial seizures of infancy with quinidine. Ann Neurol 76:457-461.

Berg AP, Sen N, and Bayliss DA (2007) TrpC3/C7 and Slo2.1 are molecular targets for metabotropic glutamate receptor signaling in rat striatal cholinergic interneurons. J Neurosci 27:8845-8856.

Bhattacharjee A, Gan L, and Kaczmarek LK (2002) Localization of the Slack potassium channel in the rat central nervous system. J Comp Neurol 454:241-254.

Bhattacharjee A, Joiner WJ, Wu M, Yang Y, Sigworth FJ, and Kaczmarek LK (2003) Slick (Slo2.1), a rapidly-gating sodium-activated potassium channel inhibited by ATP. J Neurosci 23:11681-11691.

Bhattacharjee A and Kaczmarek LK (2005) For K+ channels, Na+ is the new Ca2+. Trends Neurosci 28:422-428.

Bhattacharjee A, von Hehn CA, Mei X, and Kaczmarek LK (2005) Localization of the $\mathrm{Na}$-activated $\mathrm{K}+$ channel Slick in the rat central nervous system. J Comp Neurol 484:80-92.

Bildl W, Strassmaier T, Thurm H, Andersen J, Eble S, Oliver D, Knipper M, Mann M, Schulte U, Adelman JP, et al. (2004) Protein kinase CK2 is coassembled with small conductance $\mathrm{Ca}^{(2+)}$-activated $\mathrm{K}^{+}$channels and regulates channel gating. Neuron 43: $847-858$.

Biton B, Sethuramanujam S, Picchione KE, Bhattacharjee A, Khessibi N, Chesney F, Lanneau C, Curet O, and Avenet P (2012) The antipsychotic drug loxapine is an opener of the sodium-activated potassium channel slack (Slo2.2). J Pharmacol Exp Ther 340:706-715

Bond CT, Herson PS, Strassmaier T, Hammond R, Stackman R, Maylie J, and Adelman JP (2004) Small conductance $\mathrm{Ca}^{2+}$-activated $\mathrm{K}^{+}$channel knock-out mice reveal the identity of calcium-dependent afterhyperpolarization currents. $J$ Neurosci 24:5301-5306.

Brähler S, Kaistha A, Schmidt VJ, Wölfle SE, Busch C, Kaistha BP, Kacik M, Hasenau AL, Grgic I, Si H, et al. (2009) Genetic deficit of SK3 and IK1 channels disrupts the endothelium-derived hyperpolarizing factor vasodilator pathway and causes hypertension. Circulation 119:2323-2332.

Brenker C, Zhou Y, Müller A, Echeverry FA, Trötschel C, Poetsch A, Xia XM, Bönigk W, Lingle CJ, Kaupp UB, et al. (2014) The $\mathrm{Ca}^{2+}$-activated $\mathrm{K}^{+}$current of human sperm is mediated by Slo3. eLife 3:e01438.

Brenner R, Jegla TJ, Wickenden A, Liu Y, and Aldrich RW (2000) Cloning and functional characterization of novel large conductance calcium-activated potassium channel beta subunits, hKCNMB3 and hKCNMB4. J Biol Chem 275:6453-6461.

Brown MR, Kronengold J, Gazula VR, Chen Y, Strumbos JG, Sigworth FJ, Navaratnam D, and Kaczmarek LK (2010) Fragile X mental retardation protein controls gating of the sodium-activated potassium channel Slack. Nat Neurosci 13:819-821.

Brown MR, Kronengold J, Gazula VR, Spilianakis CG, Flavell RA, von Hehn CA Bhattacharjee A, and Kaczmarek LK (2008) Amino-termini isoforms of the Slack $\mathrm{K}^{+}$channel, regulated by alternative promoters, differentially modulate rhythmic firing and adaptation. $J$ Physiol 586:5161-5179.

Budelli G, Hage TA, Wei A, Rojas P, Jong YJ, O'Malley K, and Salkoff L (2009) $\mathrm{Na}^{+}$activated $\mathrm{K}^{+}$channels express a large delayed outward current in neurons during normal physiology. Nat Neurosci 12:745-750.

Budelli G, Sun Q, Ferreira J, Butler A, Santi CM, and Salkoff L (2016) SLO2 Channels Are Inhibited by All Divalent Cations That Activate SLO1 $\mathrm{K}^{+}$Channels. J Biol Chem 291:7347-7356.

Butler A, Tsunoda S, McCobb DP, Wei A, and Salkoff L (1993) mSlo, a complex mouse gene encoding "maxi" calcium-activated potassium channels. Science 261:221-224.

Cahalan MD and Chandy KG (2009) The functional network of ion channels in T lymphocytes. Immunol Rev 231:59-87.

Chen H, Kronengold J, Yan Y, Gazula VR, Brown MR, Ma L, Ferreira G, Yang Y, Bhattacharjee A, Sigworth FJ, et al. (2009) The N-terminal domain of Slack determines the formation and trafficking of Slick/Slack heteromeric sodium-activated potassium channels. J Neurosci 29:5654-5665.

Chen L, Tian L, MacDonald SH, McClafferty H, Hammond MS, Huibant JM, Ruth P, Knaus HG, and Shipston MJ (2005) Functionally diverse complement of large conductance calcium- and voltage-activated potassium channel (BK) alphasubunits generated from a single site of splicing. J Biol Chem 280:33599-33609.

Chen MX, Gorman SA, Benson B, Singh K, Hieble JP, Michel MC, Tate SN, and Trezise DJ (2004) Small and intermediate conductance $\mathrm{Ca}^{2+}$ )-activated $\mathrm{K}^{+}$ channels confer distinctive patterns of distribution in human tissues and differential cellular localisation in the colon and corpus cavernosum. Naunyn Schmie debergs Arch Pharmacol 369:602-615.

Christophersen P and Wulff $\mathrm{H}$ (2015) Pharmacological gating modulation of smalland intermediate-conductance $\mathrm{Ca}^{(2+)}$-activated $\mathrm{K}^{(+)}$channels (KCa2.x and KCa3.1). Channels (Austin) 9:336-343.

Contreras GF, Castillo K, Enrique N, Carrasquel-Ursulaez W, Castillo JP, Milesi V, Neely A, Alvarez O, Ferreira G, González C, et al. (2013) A BK (Slo1) channel journey from molecule to physiology. Channels (Austin) 7:442-458.
Contreras GF, Neely A, Alvarez O, Gonzalez C, and Latorre R (2012) Modulation of BK channel voltage gating by different auxiliary $\beta$ subunits. Proc Natl Acad Sci USA 109:18991-18996.

Dai L, Garg V, and Sanguinetti MC (2010) Activation of Slo2.1 channels by niflumic acid. J Gen Physiol 135:275-295

de los Angeles Tejada M, Jensen LJ, and Klaerke DA (2012a) $\mathrm{PIP}_{2}$ modulation of Slick and Slack K+ channels. Biochem Biophys Res Commun 424:208-213.

de Los Angeles Tejada M, Stolpe K, Meinild AK, and Klaerke DA (2012b) Clofilium inhibits Slick and Slack potassium channels. Biologics 6:465-470.

Devor DC, Singh AK, Frizzell RA, and Bridges RJ (1996) Modulation of Cl- secretion by benzimidazolones. I. Direct activation of a $\mathrm{Ca}^{(2+)}$-dependent $\mathrm{K}^{+}$channel. $\mathrm{Am}$ $J$ Physiol 271:L775-L784.

Dryer SE (1994) $\mathrm{Na}^{(+)}$-activated $\mathrm{K}+$ channels: a new family of large-conductance ion channels. Trends Neurosci 17:155-160.

Du W, Bautista JF, Yang H, Diez-Sampedro A, You SA, Wang L, Kotagal P, Lüders HO, Shi J, Cui J, et al. (2005) Calcium-sensitive potassium channelopathy in human epilepsy and paroxysmal movement disorder. Nat Genet 37:733-738.

Elkins T, Ganetzky B, and Wu CF (1986) A Drosophila mutation that eliminates a calcium-dependent potassium current. Proc Natl Acad Sci USA 83:8415-8419.

Faber ES, Delaney AJ, and Sah P (2005) SK channels regulate excitatory synaptic transmission and plasticity in the lateral amygdala. Nat Neurosci 8:635-641.

Faber ES and Sah P (2003) Calcium-activated potassium channels: multiple contributions to neuronal function. Neuroscientist 9:181-194.

Fanger CM, Ghanshani S, Logsdon NJ, Rauer H, Kalman K, Zhou J, Beckingham K, Chandy KG, Cahalan MD, and Aiyar J (1999) Calmodulin mediates calciumdependent activation of the intermediate conductance KCa channel, IKCa1. J Biol Chem 274:5746-5754.

Fernández-Fernández JM, Tomás M, Vázquez E, Orio P, Latorre R, Sentí M, Marrugat $\mathrm{J}$, and Valverde MA (2004) Gain-of-function mutation in the KCNMB1 potassium channel subunit is associated with low prevalence of diastolic hypertension. $J \mathrm{Clin}$ Invest 113:1032-1039.

Feske S, Wulff H, and Skolnik EY (2015) Ion channels in innate and adaptive immunity. Annu Rev Immunol 33:291-353.

Fodor AA and Aldrich RW (2009) Convergent evolution of alternative splices at domain boundaries of the BK channel. Annu Rev Physiol 71:19-36.

Gao SB, Wu Y, Lü CX, Guo ZH, Li CH, and Ding JP (2008) Slack and Slick KNa channels are required for the depolarizing afterpotential of acutely isolated, medium diameter rat dorsal root ganglion neurons. Acta Pharmacol Sin 29:899-905.

Garcia-Valdes J, Zamudio FZ, Toro L, and Possani LD (2001) Slotoxin, alphaKTx1.11, a new scorpion peptide blocker of MaxiK channels that differentiates between alpha and alpha+beta (beta1 or beta4) complexes. FEBS Lett 505:369-373.

Gardos G (1958) The function of calcium in the potassium permeability of human erythrocytes. Biochim Biophys Acta 30:653-654.

Garg P, Gardner A, Garg V, and Sanguinetti MC (2013) Structural basis of ion permeation gating in Slo2.1 $\mathrm{K}^{+}$channels. J Gen Physiol 142:523-542.

Garg P and Sanguinetti MC (2012) Structure-activity relationship of fenamates as Slo2.1 channel activators. Mol Pharmacol 82:795-802.

Garg P and Sanguinetti MC (2014) Intracellular ATP does not inhibit Slo2.1 K channels. Physiol Rep 2:e12118.

Gribkoff VK, Lum-Ragan JT, Boissard CG, Post-Munson DJ, Meanwell NA, Starrett JE Jr, Kozlowski ES, Romine JL, Trojnacki JT, Mckay MC, et al. (1996) Effects of channel modulators on cloned large-conductance calcium-activated potassium channels. Mol Pharmacol 50:206-217.

Grunnet M, Bentzen BH, Sørensen US, and Diness JG (2012) Cardiac ion channels and mechanisms for protection against atrial fibrillation. Rev Physiol Biochem Pharmacol 162:1-58.

Hammond RS, Bond CT, Strassmaier T, Ngo-Anh TJ, Adelman JP, Maylie J, and Stackman RW (2006) Small-conductance Ca2+-activated $\mathrm{K}+$ channel type 2 (SK2) modulates hippocampal learning, memory, and synaptic plasticity. $J$ Neurosci 26:1844-1853.

Heron SE, Smith KR, Bahlo M, Nobili L, Kahana E, Licchetta L, Oliver KL, Mazarib A, Afawi Z, Korczyn A, et al. (2012) Missense mutations in the sodium-gated potassium channel gene KCNT1 cause severe autosomal dominant nocturnal fronta lobe epilepsy. Nat Genet 44:1188-1190.

Hite RK, Yuan P, Li Z, Hsuing Y, Walz T, and MacKinnon R (2015) Cryo-electron microscopy structure of the Slo2.2 $\mathrm{Na}(+)$-activated $\mathrm{K}(+)$ channel. Nature 527: 198-203.

Hoffman JF, Joiner W, Nehrke K, Potapova O, Foye K, and Wickrema A (2003) The hSK4 (KCNN4) isoform is the Ca2+-activated $\mathrm{K}+$ channel (Gardos channel) in human red blood cells. Proc Natl Acad Sci USA 100:7366-7371.

Horrigan FT and Aldrich RW (1999) Allosteric voltage gating of potassium channels II. Mslo channel gating charge movement in the absence of $\mathrm{Ca}^{(2+)}$. J Gen Physiol 114:305-336.

Horrigan FT and Aldrich RW (2002) Coupling between voltage sensor activation, Ca2 + binding and channel opening in large conductance (BK) potassium channels. $J$ Gen Physiol 120:267-305.

Huang F, Wang X, Ostertag EM, Nuwal T, Huang B, Jan YN, Basbaum AI, and Jan LY (2013) TMEM16C facilitates $\mathrm{Na}^{(+)}$-activated $\mathrm{K}^{+}$currents in rat sensory neurons and regulates pain processing. Nat Neurosci 16:1284-1290.

Huang X, He Y, Dubuc AM, Hashizume R, Zhang W, Reimand J, Yang H, Wang TA Stehbens SJ, Younger S, et al. (2015) EAG2 potassium channel with evolutionarily conserved function as a brain tumor target. Nat Neurosci 18:1236-1246.

Iossifov I, O'Roak BJ, Sanders SJ, Ronemus M, Krumm N, Levy D, Stessman HA Witherspoon KT, Vives L, Patterson KE, et al. (2014) The contribution of de novo coding mutations to autism spectrum disorder. Nature 515:216-221.

Ishii A, Shioda M, Okumura A, Kidokoro H, Sakauchi M, Shimada S, Shimizu T, Osawa M, Hirose S, and Yamamoto T (2013) A recurrent KCNT1 mutation in two sporadic cases with malignant migrating partial seizures in infancy. Gene 531: $467-471$

Ishii TM, Maylie J, and Adelman JP (1997a) Determinants of apamin and d-tubocurarine block in SK potassium channels. J Biol Chem 272:23195-23200. 
Ishii TM, Silvia C, Hirschberg B, Bond CT, Adelman JP, and Maylie J (1997b) A human intermediate conductance calcium-activated potassium channel. Proc Natl Acad Sci USA 94:11651-11656.

Jiang Y, Lee A, Chen J, Cadene M, Chait BT, and MacKinnon R (2002) Crystal structure and mechanism of a calcium-gated potassium channel. Nature 417: $515-522$

Joiner WJ, Khanna R, Schlichter LC, and Kaczmarek LK (2001) Calmodulin regulates assembly and trafficking of SK4/IK1 $\mathrm{Ca}^{2+}$-activated $\mathrm{K}^{+}$channels. J Biol Chem 276: 37980-37985.

Joiner WJ, Tang MD, Wang LY, Dworetzky SI, Boissard CG, Gan L, Gribkoff VK and Kaczmarek LK (1998) Formation of intermediate-conductance calcium-activated potassium channels by interaction of Slack and Slo subunits. Nat Neurosci 1:462-469.

Joiner WJ, Wang LY, Tang MD, and Kaczmarek LK (1997) hSK4, a member of a novel subfamily of calcium-activated potassium channels. Proc Natl Acad Sci USA 94:11013-11018.

Juang JM, Lu TP, Lai LC, Ho CC, Liu YB, Tsai CT, Lin LY, Yu CC, Chen WJ, Chiang FT, et al. (2014) Disease-targeted sequencing of ion channel genes identifies de novo mutations in patients with non-familial Brugada syndrome. Sci Rep 4:6733.

Kaczmarek LK (2013) Slack, Slick and Sodium-Activated Potassium Channels. ISRN Neurosci 2013:354262 10.1155/2013/354262.

Kaczorowski GJ, Knaus HG, Leonard RJ, McManus OB, and Garcia ML (1996) Highconductance calcium-activated potassium channels; structure, pharmacology, and function. J Bioenerg Biomembr 28:255-267.

Kameyama M, Kakei M, Sato R, Shibasaki T, Matsuda H, and Irisawa H (1984) Intracellular $\mathrm{Na}^{+}$activates a $\mathrm{K}^{+}$channel in mammalian cardiac cells. Nature 309: 354-356.

Kim GE and Kaczmarek LK (2014) Emerging role of the KCNT1 Slack channel in intellectual disability. Front Cell Neurosci 8: DOI:10.3389/fncel.2014.00209.

Kim GE, Kronengold J, Barcia G, Quraishi IH, Martin HC, Blair E, Taylor JC, Dulac O, Colleaux L, Nabbout R, et al. (2014) Human slack potassium channel mutations increase positive cooperativity between individual channels. Cell Reports 9:1661-1672.

King B, Rizwan AP, Asmara H, Heath NC, Engbers JD, Dykstra S, Bartoletti TM, Hameed S, Zamponi GW, and Turner RW (2015) IKCa channels are a critical determinant of the slow AHP in CA1 pyramidal neurons. Cell Reports 11:175-182.

Klement G, Druzin M, Haage D, Malinina E, Arhem P, and Johansson S (2010) Spontaneous ryanodine-receptor-dependent $\mathrm{Ca}^{2+}$-activated $\mathrm{K}^{+}$currents and hyperpolarizations in rat medial preoptic neurons. J Neurophysiol 103:2900-2911.

Köhler M, Hirschberg B, Bond CT, Kinzie JM, Marrion NV, Maylie J, and Adelman JP (1996) Small-conductance, calcium-activated potassium channels from mammalian brain. Science 273:1709-1714.

Krnjević K and Lisiewicz A (1972) Injections of calcium ions into spinal motoneurones. J Physiol 225:363-390.

Lagrutta A, Shen KZ, North RA, and Adelman JP (1994) Functional differences among alternatively spliced variants of Slowpoke, a Drosophila calcium-activated potassium channel. J Biol Chem 269:20347-20351.

Lam J, Coleman N, Garing AL, and Wulff H (2013) The therapeutic potential of small-conductance $\mathrm{KCa} 2$ channels in neurodegenerative and psychiatric diseases. Expert Opin Ther Targets 17:1203-1220.

Lamy C, Goodchild SJ, Weatherall KL, Jane DE, Liégeois JF, Seutin V, and Marrion NV (2010) Allosteric block of KCa2 channels by apamin. J Biol Chem 285:27067-27077.

Latorre R, Vergara C, and Hidalgo C (1982) Reconstitution in planar lipid bilayers of a $\mathrm{Ca}^{2+}$-dependent $\mathrm{K}^{+}$channel from transverse tubule membranes isolated from rabbit skeletal muscle. Proc Natl Acad Sci USA 79:805-809.

Leonetti MD, Yuan P, Hsiung Y, and Mackinnon R (2012) Functional and structural analysis of the human SLO3 pH- and voltage-gated $\mathrm{K}^{+}$channel. Proc Natl Acad Sci USA 109:19274-19279.

Li Y, Johnson G, Romine JL, Meanwell NA, Martin SW, Dworetzky SI, Boissard CG, Gribkoff VK, and Starrett JE Jr (2003) Novel openers of $\mathrm{Ca}^{2+}$-dependent largeconductance potassium channels: symmetrical pharmacophore and electrophysiological evaluation of bisphenols. Bioorg Med Chem Lett 13:1437-1439

Lin MT, Luján R, Watanabe M, Adelman JP, and Maylie J (2008) SK2 channel plasticity contributes to LTP at Schaffer collateral-CA1 synapses. Nat Neurosci 11: $170-177$.

Logsdon NJ, Kang J, Togo JA, Christian EP, and Aiyar J (1997) A novel gene, hKCa4 encodes the calcium-activated potassium channel in human T lymphocytes. J Biol Chem 272:32723-32726.

Lu R, Bausch AE, Kallenborn-Gerhardt W, Stoetzer C, Debruin N, Ruth P, Geisslinger G, Leffler A, Lukowski R, and Schmidtko A (2015) Slack channels expressed in sensory neurons control neuropathic pain in mice. J Neurosci 35:1125-1135.

Lu S, Das P, Fadool DA, and Kaczmarek LK (2010) The slack sodium-activated potassium channel provides a major outward current in olfactory neurons of Kv1.3-/- super-smeller mice. J Neurophysiol 103:3311-3319.

$\mathrm{Ma}$ Z, Lou XJ, and Horrigan FT (2006) Role of charged residues in the S1-S4 voltage sensor of BK channels. J Gen Physiol 127:309-328.

Mannowetz N, Naidoo NM, Choo SA, Smith JF, and Lishko PV (2013) Slo1 is the principal potassium channel of human spermatozoa. eLife 2:e01009.

Marrion NV and Tavalin SJ (1998) Selective activation of $\mathrm{Ca}^{2+}$-activated $\mathrm{K}^{+}$channels by co-localized Ca2+ channels in hippocampal neurons. Nature 395:900-905.

Martin HC, Kim GE, Pagnamenta AT, Murakami Y, Carvill GL, Meyer E, Copley RR, Rimmer A, Barcia G, Fleming MR, et al.; WGS500 Consortium (2014) Clinical whole-genome sequencing in severe early-onset epilepsy reveals new genes and improves molecular diagnosis. Hum Mol Genet 23:3200-3211.

Martinez-Espinosa PL, Wu J, Yang C, Gonzalez-Perez V, Zhou H, Liang H, Xia XM, and Lingle CJ (2015) Knockout of Slo2.2 enhances itch, abolishes KNa current, and increases action potential firing frequency in DRG neurons. eLife 4:e10013.

Marty A (1981) Ca-dependent $K$ channels with large unitary conductance in chromaffin cell membranes. Nature 291:497-500.

McTague A, Appleton R, Avula S, Cross JH, King MD, Jacques TS, Bhate S, Cronin A, Curran A, Desurkar A, et al. (2013) Migrating partial seizures of infancy: expansion of the electroclinical, radiological and pathological disease spectrum. Brain 136:1578-1591.
Meech RW (1972) Intracellular calcium injection causes increased potassium conductance in Aplysia nerve cells. Comp Biochem Physiol A 42:493-499.

Meera P, Wallner M, Song M, and Toro L (1997) Large conductance voltage- and calcium-dependent $\mathrm{K}+$ channel, a distinct member of voltage-dependent ion channels with seven N-terminal transmembrane segments (S0-S6), an extracellular N terminus, and an intracellular (S9-S10) C terminus. Proc Natl Acad Sci USA 94: 14066-14071.

Milligan CJ, Li M, Gazina EV, Heron SE, Nair U, Trager C, Reid CA, Venkat A, Younkin DP, Dlugos DJ, et al. (2014) KCNT1 gain of function in 2 epilepsy phenotypes is reversed by quinidine. Ann Neurol 75:581-590.

Miranda P, Contreras JE, Plested AJ, Sigworth FJ, Holmgren M, and Giraldez T (2013) State-dependent FRET reports calcium- and voltage-dependent gating-ring motions in BK channels. Proc Natl Acad Sci USA 110:5217-5222.

Mulholland PJ, Hopf FW, Bukiya AN, Martin GE, Liu J, Dopico AM, Bonci A, Treistman SN, and Chandler LJ (2009) Sizing up ethanol-induced plasticity: the role of small and large conductance calcium-activated potassium channels. Alcohol Clin Exp Res 33:1125-1135.

Navaratnam DS, Bell TJ, Tu TD, Cohen EL, and Oberholtzer JC (1997) Differential distribution of $\mathrm{Ca} 2+$-activated $\mathrm{K}+$ channel splice variants among hair cells along the tonotopic axis of the chick cochlea. Neuron 19:1077-1085.

Navarro B, Kirichok Y, and Clapham DE (2007) KSper, a pH-sensitive K+ current that controls sperm membrane potential. Proc Natl Acad Sci USA 104:7688-7692. Ngo-Anh TJ, Bloodgood BL, Lin M, Sabatini BL, Maylie J, and Adelman JP (2005) SK channels and NMDA receptors form a Ca2+-mediated feedback loop in dendritic spines. Nat Neurosci 8:642-649.

Nolting A, Ferraro T, D'hoedt D, and Stocker M (2007) An amino acid outside the pore region influences apamin sensitivity in small conductance $\mathrm{Ca}^{2+}$-activated $\mathrm{K}^{+}$ channels. J Biol Chem 282:3478-3486.

Nuwer MO, Picchione KE, and Bhattacharjee A (2010) PKA-induced internalization of slack $\mathrm{KNa}$ channels produces dorsal root ganglion neuron hyperexcitability. $J$ Neurosci 30:14165-14172.

Oliver D, Klöcker N, Schuck J, Baukrowitz T, Ruppersberg JP, and Fakler B (2000) Gating of $\mathrm{Ca}^{2+}$-activated $\mathrm{K}^{+}$channels controls fast inhibitory synaptic transmission at auditory outer hair cells. Neuron 26:595-601.

Pallotta BS, Magleby KL, and Barrett JN (1981) Single channel recordings of $\mathrm{Ca}^{2+}$-activated $\mathrm{K}^{+}$currents in rat muscle cell culture. Nature 293:471-474.

Paulais M, Lachheb S, and Teulon $\mathrm{J}(2006) \mathrm{A} \mathrm{Na}^{+}$- and $\mathrm{Cl}^{-}$-activated $\mathrm{K}+$ channel in the thick ascending limb of mouse kidney. J Gen Physiol 127:205-215.

Power JM and Sah P (2008) Competition between calcium-activated K+ channels determines cholinergic action on firing properties of basolateral amygdala projection neurons. J Neurosci 28:3209-3220.

Rajan AS, Aguilar-Bryan L, Nelson DA, Yaney GC, Hsu WH, Kunze DL, and Boyd AE 3rd (1990) Ion channels and insulin secretion. Diabetes Care 13:340-363.

Rizzi S, Knaus HG, and Schwarzer C (2016) Differential distribution of the sodiumactivated potassium channels slick and slack in mouse brain. J Comp Neurol 524: 2093-2116.

Rizzi S, Schwarzer C, Kremser L, Lindner HH, and Knaus HG (2015) Identification of potential novel interaction partners of the sodium-activated potassium channels Slick and Slack in mouse brain. Biochem Biophys Rep 4:291-298.

Rizzo F, Ambrosino P, Guacci A, Chetta M, Marchese G, Rocco T, Soldovieri MV Manocchio L, Mosca I, Casara G, et al. (2016) Characterization of two de novoKCNT1 mutations in children with malignant migrating partial seizures in infancy. Mol Cell Neurosci 72:54-63.

Roberts WM, Jacobs RA, and Hudspeth AJ (1990) Colocalization of ion channels involved in frequency selectivity and synaptic transmission at presynaptic active zones of hair cells. $J$ Neurosci 10:3664-3684.

Rosenbaum ST, Svalø J, Nielsen K, Larsen T, Jørgensen JC, and Bouchelouche P (2012) Immunolocalization and expression of small-conductance calcium-activated potassium channels in human myometrium. J Cell Mol Med 16:3001-3008.

Rosenblatt KP, Sun ZP, Heller S, and Hudspeth AJ (1997) Distribution of $\mathrm{Ca} 2+$-activated $\mathrm{K}+$ channel isoforms along the tonotopic gradient of the chicken's cochlea. Neuron 19:1061-1075.

Ruffin VA, Gu XQ, Zhou D, Douglas RM, Sun X, Trouth CO, and Haddad GG (2008) The sodium-activated potassium channel Slack is modulated by hypercapnia and acidosis. Neuroscience 151:410-418.

Sailer CA, Hu H, Kaufmann WA, Trieb M, Schwarzer C, Storm JF, and Knaus HG (2002) Regional differences in distribution and functional expression of small-conductance Ca2+-activated $\mathrm{K}+$ channels in rat brain. J Neurosci 22 9698-9707.

Sánchez-Carranza O, Torres-Rodríguez P, Darszon A, Treviño CL, and López-González I (2015) Pharmacology of hSlo3 channels and their contribution in the capacitationassociated hyperpolarization of human sperm. Biochem Biophys Res Commun 466: 554-559.

Sanchez M and McManus OB (1996) Paxilline inhibition of the alpha-subunit of the high-conductance calcium-activated potassium channel. Neuropharmacology 35: 963-968.

Santi CM, Ferreira G, Yang B, Gazula VR, Butler A, Wei A, Kaczmarek LK, and Salkoff L (2006) Opposite regulation of Slick and Slack $\mathrm{K}^{+}$channels by neuromodulators. $J$ Neurosci 26:5059-5068.

Santi CM, Martínez-López P, de la Vega-Beltrán JL, Butler A, Alisio A, Darszon A and Salkoff L (2010) The SLO3 sperm-specific potassium channel plays a vital role in male fertility. FEBS Lett 584:1041-1046.

Schreiber M and Salkoff L (1997) A novel calcium-sensing domain in the BK channel. Biophys J 73:1355-1363.

Schreiber M, Wei A, Yuan A, Gaut J, Saito M, and Salkoff L (1998) Slo3, a novel $\mathrm{pH}$-sensitive $\mathrm{K}+$ channel from mammalian spermatocytes. J Biol Chem 273: 3509-3516.

Seibold MA, Wang B, Eng C, Kumar G, Beckman KB, Sen S, Choudhry S, Meade K, Lenoir M, Watson HG, et al. (2008) An african-specific functional polymorphism in KCNMB1 shows sex-specific association with asthma severity. Hum Mol Genet 17: 2681-2690. 
Singh H, Stefani E, and Toro L (2012) Intracellular BK(Ca) (iBK(Ca)) channels. $J$ Physiol 590:5937-5947.

Stefani E, Ottolia M, Noceti F, Olcese R, Wallner M, Latorre R, and Toro L (1997) Voltage-controlled gating in a large conductance $\mathrm{Ca}^{2+}$-sensitive $\mathrm{K}^{+}$channel (hslo). Proc Natl Acad Sci USA 94:5427-5431.

Stocker $\mathrm{M}(2004) \mathrm{Ca}^{(2+)}$-activated $\mathrm{K}^{+}$channels: molecular determinants and function of the SK family. Nat Rev Neurosci 5:758-770.

Stocker M and Pedarzani P (2000) Differential distribution of three $\mathrm{Ca}^{(2+)}$-activated $\mathrm{K}^{(+)}$channel subunits, SK1, SK2, and SK3, in the adult rat central nervous system. Mol Cell Neurosci 15:476-493.

Sui JL, Chan KW, and Logothetis DE (1996) Na+ activation of the muscarinic K+ channel by a G-protein-independent mechanism. J Gen Physiol 108:381-391.

Tamsett TJ, Picchione KE, and Bhattacharjee A (2009) NAD+ activates KNa channels in dorsal root ganglion neurons. J Neurosci 29:5127-5134.

Tang QY, Zhang FF, Xu J, Wang R, Chen J, Logothetis DE, and Zhang Z (2016) Epilepsy-related Slack channel mutants lead to channel over-activity by two different mechanisms. Cell Reports 14:129-139.

Tang QY, Zhang Z, Xia XM, and Lingle CJ (2010) Block of mouse Slo1 and Slo3 $\mathrm{K}^{+}$ channels by CTX, IbTX, TEA, 4-AP and quinidine. Channels (Austin) 4:22-41.

Tang XD, Xu R, Reynolds MF, Garcia ML, Heinemann SH, and Hoshi T (2003) Haem can bind to and inhibit mammalian calcium-dependent Slo1 BK channels. Nature 425:531-535.

Taylor MS, Bonev AD, Gross TP, Eckman DM, Brayden JE, Bond CT, Adelman JP, and Nelson MT (2003) Altered expression of small-conductance $\mathrm{Ca}^{2+}$-activated $\mathrm{K}^{+}$ (SK3) channels modulates arterial tone and blood pressure. Circ Res 93:124-131.

Tejada MA, Stople K, Hammami Bomholtz S, Meinild AK, Poulsen AN, and Klaerke DA (2014) Cell volume changes regulate slick (Slo2.1), but not slack (Slo2.2) $\mathrm{K}_{+}$ channels. PLoS One 9:e110833.

Thomson SJ, Hansen A, and Sanguinetti MC (2015) Identification of the Intracellular $\mathrm{Na}^{+}$Sensor in Slo2.1 Potassium Channels. J Biol Chem 290:14528-14535.

Tomasello DL, Gancarz-Kausch AM, Dietz DM, and Bhattacharjee A (2015) Transcriptional regulation of the sodium-activated potassium channel SLICK (KCNT2 promoter by nuclear factor-кB. J Biol Chem 290:18575-18583.

Treistman SN and Martin GE (2009) BK Channels: mediators and models for alcohol tolerance. Trends Neurosci 32:629-637.

Turner RW, Kruskic M, Teves M, Scheidl-Yee T, Hameed S, and Zamponi GW (2015) Neuronal expression of the intermediate conductance calcium-activated potassium channel KCa3.1 in the mammalian central nervous system. Pflugers Arch 467: 311-328.

Uchino S, Wada H, Honda S, Hirasawa T, Yanai S, Nakamura Y, Ondo Y, and Kohsaka S (2003) Slo2 sodium-activated $\mathrm{K}^{+}$channels bind to the PDZ domain of PSD-95. Biochem Biophys Res Commun 310:1140-1147.

Uebele VN, Lagrutta A, Wade T, Figueroa DJ, Liu Y, McKenna E, Austin CP, Bennett PB, and Swanson R (2000) Cloning and functional expression of two families of betasubunits of the large conductance calcium-activated $\mathrm{K}^{+}$channel. J Biol Chem 275:23211-23218.

Vanderver A, Simons C, Schmidt JL, Pearl PL, Bloom M, Lavenstein B, Miller D, Grimmond SM, and Taft RJ (2014) Identification of a novel de novo p.Phe932Ile KCNT1 mutation in a patient with leukoencephalopathy and severe epilepsy. Pediatr Neurol 50:112-114.

Vandorpe DH, Shmukler BE, Jiang L, Lim B, Maylie J, Adelman JP, de Franceschi L, Cappellini MD, Brugnara C, and Alper SL (1998) cDNA cloning and functional characterization of the mouse $\mathrm{Ca}^{2+}$-gated $\mathrm{K}^{+}$channel, mIK1. Roles in regulatory volume decrease and erythroid differentiation. J Biol Chem 273:21542-21553.

Wang K, Mateos-Aparicio P, Hönigsperger C, Raghuram V, Wu WW, Ridder MC, Sah P, Maylie J, Storm JF, and Adelman JP (2016) IK1 channels do not contribute to the slow afterhyperpolarization in pyramidal neurons. eLife 5:e11206.

Wang L and Sigworth FJ (2009) Structure of the BK potassium channel in a lipid membrane from electron cryomicroscopy. Nature 461:292-295.

Wang RX, Shi HF, Chai Q, Wu Y, Sun W, Ji Y, Yao Y, Li KL, Zhang CY, Zheng J, et al. (2012) Molecular mechanisms of diabetic coronary dysfunction due to large conductance $\mathrm{Ca}^{+}$-activated $\mathrm{K}^{+}$channel impairment. Chin Med J (Engl) 125: $2548-2555$

Wei AD, Gutman GA, Aldrich R, Chandy KG, Grissmer S, and Wulff H (2005) International Union of Pharmacology. LII. Nomenclature and molecular relationships of calcium-activated potassium channels. Pharmacol Rev 57:463-472.

Wojtovich AP, Sherman TA, Nadtochiy SM, Urciuoli WR, Brookes PS, and Nehrke K (2011) SLO-2 is cytoprotective and contributes to mitochondrial potassium transport. PLoS One 6:e28287.

Wrighton DC, Muench SP, and Lippiat JD (2015) Mechanism of inhibition of mouse Slo3 (KCa 5.1) potassium channels by quinine, quinidine and barium. $\mathrm{Br} J \mathrm{Phar}-$ macol 172:4355-4363.

Wu Y, Yang Y, Ye S, and Jiang Y (2010) Structure of the gating ring from the human large-conductance $\mathrm{Ca}^{(2+)}$-gated $\mathrm{K}^{(+)}$channel. Nature 466:393-397.
Wulff H and Castle NA (2010) Therapeutic potential of KCa3.1 blockers: recent advances and promising trends. Expert Rev Clin Pharmacol 3:385-396.

Wulff $\mathrm{H}$ and Christophersen $\mathrm{P}$ (2015) Recent developments in ion channel pharmacology. Channels (Austin) 9:335.

Wulff H and Köhler R (2013) Endothelial small-conductance and intermediateconductance KCa channels: an update on their pharmacology and usefulness as cardiovascular targets. $J$ Cardiovasc Pharmacol 61:102-112.

Wulff H, Miller MJ, Hansel W, Grissmer S, Cahalan MD, and Chandy KG (2000) Design of a potent and selective inhibitor of the intermediate-conductance $\mathrm{Ca}^{2+}$-activated $\mathrm{K}^{+}$channel, IKCa1: a potential immunosuppressant. Proc Natl Acad Sci USA 97:8151-8156.

Xia XM, Ding JP, Zeng XH, Duan KL, and Lingle CJ (2000) Rectification and rapid activation at low $\mathrm{Ca}^{2+}$ of $\mathrm{Ca}^{2+}$-activated, voltage-dependent $\mathrm{BK}$ currents: consequences of rapid inactivation by a novel beta subunit. J Neurosci 20:4890-4903.

Xia XM, Fakler B, Rivard A, Wayman G, Johnson-Pais T, Keen JE, Ishii T, Hirschberg B, Bond CT, Lutsenko S, et al. (1998) Mechanism of calcium gating in small-conductance calcium-activated potassium channels. Nature 395:503-507.

Xie J and McCobb DP (1998) Control of alternative splicing of potassium channels by stress hormones. Science 280:443-446.

Yan J and Aldrich RW (2012) BK potassium channel modulation by leucine-rich repeat-containing proteins. Proc Natl Acad Sci USA 109:7917-7922.

Yan Y, Yang Y, Bian S, and Sigworth FJ (2012) Expression, purification and functional reconstitution of slack sodium-activated potassium channels. J Membr Biol 245:667-674

Yang B, Desai R, and Kaczmarek LK (2007) Slack and Slick K(Na) channels regulate the accuracy of timing of auditory neurons. J Neurosci 27:2617-2627.

Yang B, Gribkoff VK, Pan J, Damagnez V, Dworetzky SI, Boissard CG, Bhattacharjee A, Yan Y, Sigworth FJ, and Kaczmarek LK (2006) Pharmacological activation and inhibition of Slack (Slo2.2) channels. Neuropharmacology 51:896-906.

Yang J, Krishnamoorthy G, Saxena A, Zhang G, Shi J, Yang H, Delaloye K, Sept D, and Cui J (2010) An epilepsy/dyskinesia-associated mutation enhances BK channel activation by potentiating $\mathrm{Ca}^{2+}$ sensing. Neuron 66:871-883.

Yuan A, Dourado M, Butler A, Walton N, Wei A, and Salkoff L (2000) SLO-2, a K ${ }^{+}$ channel with an unusual $\mathrm{Cl}^{-}$dependence. Nat Neurosci 3:771-779.

Yuan A, Santi CM, Wei A, Wang ZW, Pollak K, Nonet M, Kaczmarek L, Crowder CM, and Salkoff L (2003) The sodium-activated potassium channel is encoded by a member of the Slo gene family. Neuron 37:765-773.

Yuan P, Leonetti MD, Hsiung Y, and MacKinnon R (2012) Open structure of the $\mathrm{Ca}^{2+}$ gating ring in the high-conductance $\mathrm{Ca} 2+$-activated $\mathrm{K}+$ channel. Nature 481:94-97.

Yuan P, Leonetti MD, Pico AR, Hsiung Y, and MacKinnon R (2010) Structure of the human BK channel $\mathrm{Ca} 2+$-activation apparatus at $3.0 \mathrm{~A}$ resolution. Science 329: 182-186.

Zeng XH, Navarro B, Xia XM, Clapham DE, and Lingle CJ (2013) Simultaneous knockout of Slo3 and CatSper1 abolishes all alkalization- and voltage-activated current in mouse spermatozoa. J Gen Physiol 142:305-313.

Zeng XH, Yang C, Kim ST, Lingle CJ, and Xia XM (2011) Deletion of the Slo3 gene abolishes alkalization-activated $\mathrm{K}+$ current in mouse spermatozoa. Proc Natl Acad Sci USA 108:5879-5884.

Zeng XH, Yang C, Xia XM, Liu M, and Lingle CJ (2015) SLO3 auxiliary subunit LRRC52 controls gating of sperm KSPER currents and is critical for normal fertility. Proc Natl Acad Sci USA 112:2599-2604.

Zhang L, Sukhareva M, Barker JL, Maric D, Hao Y, Chang YH, Ma W, O'Shaughnessy $\mathrm{T}$, and Rubinow DR (2005) Direct binding of estradiol enhances Slack (sequence like a calcium-activated potassium channel) channels' activity. Neuroscience 131:275-282.

Zhang M, Pascal JM, Schumann M, Armen RS, and Zhang JF (2012a) Identification of the functional binding pocket for compounds targeting small-conductance $\mathrm{Ca}^{2+}$-activated potassium channels. Nat Commun 3:1021.

Zhang M, Pascal JM, and Zhang JF (2013a) Unstructured to structured transition of an intrinsically disordered protein peptide in coupling $\mathrm{Ca}^{2+}$-sensing and SK channel activation. Proc Natl Acad Sci USA 110:4828-4833.

Zhang X, Zeng X, and Lingle CJ (2006a) Slo3 K+ channels: voltage and pH dependence of macroscopic currents. J Gen Physiol 128:317-336.

Zhang X, Zeng X, Xia XM, and Lingle CJ (2006b) pH-regulated Slo3 $\mathrm{K}^{+}$channels: properties of unitary currents. J Gen Physiol 128:301-315.

Zhang Y, Brown MR, Hyland C, Chen Y, Kronengold J, Fleming MR, Kohn AB, Moroz LL, and Kaczmarek LK (2012b) Regulation of neuronal excitability by interaction of fragile X mental retardation protein with slack potassium channels. $J$ Neurosci 32:15318-15327.

Zhang Z, Rosenhouse-Dantsker A, Tang QY, Noskov S, and Logothetis DE (2010) The RCK2 domain uses a coordination site present in Kir channels to confer sodium sensitivity to Slo2.2 channels. J Neurosci 30:7554-7562.

Zhang Z, Tang QY, Alaimo JT, Davies AG, Bettinger JC, and Logothetis DE (2013b) SLO-2 isoforms with unique $\mathrm{Ca}\left({ }^{2+}\right)$ - and voltage-dependence characteristics confer sensitivity to hypoxia in C. elegans. Channels (Austin) 7:194-205. 